\title{
Re-evaluation of the ages of ${ }^{40} \mathrm{Ar} /{ }^{39} \mathrm{Ar}$ sanidine standards and supereruptions in the western U.S. using a Noblesse multi-collector mass spectrometer
}

\author{
Brian R. Jicha ${ }^{*}$, Brad S. Singer, Peter Sobol \\ Department of Geoscience, University of Wisconsin-Madison, Madison, Wisconsin, 53706 \\ *Email: brian.jicha@wisc.edu
}

10 ABSTRACT

11 The rewards from resolving the tempo of magmatic, paleobiologic, paleoclimatic, and tectonic processes

12 at better than the per mil level of precision have spurred a quest within the geochronology community to

13 improve the precision, accuracy, and calibration of several chronometers, including the ${ }^{40} \mathrm{Ar} /{ }^{39} \mathrm{Ar}$ variant

14 of the K-Ar clock. A new generation of multi-collector mass spectrometers for ${ }^{40} \mathrm{Ar} /{ }^{39} \mathrm{Ar}$ geochronology

15 provides the means to address these issues, as well as to evaluate the ages of ${ }^{40} \mathrm{Ar} /{ }^{39} \mathrm{Ar}$ standards and key

16 marker horizons deposited by large volume, caldera-forming supereruptions in the western U.S. at

17 unprecedented temporal resolution. We highlight the utility of a 5-collector Noblesse mass spectrometer

18 that has a sufficiently high mass resolving power to distinguish ${ }^{36} \mathrm{Ar}+\mathrm{H}^{35} \mathrm{Cl}$ from a ${ }^{36} \mathrm{Ar}+\mathrm{H}^{35} \mathrm{Cl}+{ }^{12} \mathrm{C}_{3}$

19 sum peak at m/e 36, maintains a remarkably low and stable background, and thus yields ${ }^{40} \mathrm{Ar} /{ }^{39} \mathrm{Ar}$ dates of

20 exceptionally high precision. We have calibrated a reference gas and developed a simple analytical

21 routine involving one peak hop, both of which are used to evaluate detector-bias correction factors.

22 Because the ${ }^{40} \mathrm{Ar} /{ }^{39} \mathrm{Ar}$ chronometer is a relative dating technique that relies on calibration against mineral

23 standards of known age, precise and accurate determination of the ages of these standards, and

24 verification of isotopic composition and homogeneity, is essential. We present results from both total

25 fusion and incremental heating experiments on single crystals of the widely used Alder Creek (ACs) and

26 Fish Canyon (FCs) sanidine standards. Several recent, independent, measurements of ACs using multi-

27 collector mass spectrometers, including those presented herein, favor an age of $1.1864 \pm 0.0003 / 0.0012$

$28 \mathrm{Ma}(95 \%$ confidence analytical/full external uncertainty), that is $>1 \%$ younger than the widely used value

29 obtained by Nomade et al. (2005) using a single collector mass spectrometer. Incremental-heating 
experiments on single crystals of FCs most commonly do not yield plateau ages, instead many crystals appear to be affected by Ar loss or excess Ar. Our findings, obtained using ion counters, independently confirm those recently obtained using a multiple-Faraday detectors or a combination of Faraday and ion counting detectors. Thus, careful consideration must be given to using FCs in future high-precision

${ }^{40} \mathrm{Ar} /{ }^{39} \mathrm{Ar}$ calibrations of the geologic timescale. Notwithstanding, ${ }^{40} \mathrm{Ar} /{ }^{39} \mathrm{Ar}$ dating of sanidine using the 5- collector Noblesse can now provide leverage critical to interpreting the large range of U-Pb zircon dates commonly found in rhyolitic lavas and tuffs. a versatile geochronometer used to date some of the youngest volcanism on Earth (e.g., Renne et al., magnetic sector, single collector mass spectrometers that are operated in a peak-hopping mode. During

\section{Introduction}

1997) as well as meteorites that formed during the early history of the solar system (Cassata et al., 2010).

In large part as a result of the EARTHTIME initiative that began in 2003, and the recognition of systematic discrepancies between the K-Ar and U-Pb chronometers (Renne et al., 1998; Schoene et al., 2006; Kuiper et al., 2008), demand for improved precision, accuracy, and mass resolution for ${ }^{40} \mathrm{Ar} /{ }^{39} \mathrm{Ar}$ measurements has increased (Schmitz and Kuiper, 2013). Part of this stimulus reflects the rapidly growing use of the $\mathrm{U}-\mathrm{Pb}$ geochronometer on Phanerozoic rocks. Precise $(< \pm 1 \%)$ and accurate U-Pb ages are possible due to the development chemical abrasion isotope dilution thermal ionization (CAIDTIMS) methods aimed at eliminating the effects of Pb loss (Mattinson, 2005; Mundil et al., 2004), creation and distribution of the EARTHTIME tracer (Condon et al., 2015), refinement of the isotopic composition of natural uranium (Condon et al., 2010; Hiess et al., 2012), and reduction of analytical and systematic uncertainties (Schmitz and Schoene, 2007; McLean et al., 2011; 2015).

Until recently, the vast majority of instruments developed for ${ }^{40} \mathrm{Ar} /{ }^{39} \mathrm{Ar}$ geochronology have been analysis of the gas, the magnetic field strength is changed to direct the various isotopes of Ar onto a single collector. A new generation of multi-collector mass spectrometers for ${ }^{40} \mathrm{Ar} /{ }^{39} \mathrm{Ar}$ geochronology is now 
becoming more widely used than the traditional single collector instruments (e.g., Mark et al., 2009; Brumm et al., 2010; Rivera et al., 2011; Phillips and Matchan, 2013; Singer et al., 2014; Mercer et al., 2015; Dimaggio et al., 2015). These multi-collector mass spectrometers offer improved precision, higher mass resolution in some cases, and a dramatic reduction in the sample size required for ${ }^{40} \mathrm{Ar} /{ }^{39} \mathrm{Ar}$ analysis. However, detector calibration has hampered routine use for some detector configurations (e.g., Coble et 61 al., 2011). evaluate detector-bias correction factors for our 5-collector $\mathrm{Nu}$ Instruments Noblesse mass spectrometer.

64 We re-evaluate the ages of a Cretaceous and a Quaternary supereruption, and build upon several recent 65 attempts to calibrate the ages of two commonly used ${ }^{40} \mathrm{Ar} /{ }^{39} \mathrm{Ar}$ mineral standards, the Alder Creek rhyolite sanidine (ACs; Turrin et al., 1994; Renne et al., 1998; Nomade et al., 2005) and the Fish Canyon Tuff sanidine (FCs; Renne et al., 1998; Kuiper et al., 2008; Rivera et al., 2011). Because the ${ }^{40} \mathrm{Ar} /{ }^{39} \mathrm{Ar}$ method is a relative dating technique, ${ }^{40} \mathrm{Ar} /{ }^{39} \mathrm{Ar}$ ages are referenced to a mineral standard of known age. Thus, precise and accurate determination of ${ }^{40} \mathrm{Ar} /{ }^{39} \mathrm{Ar}$ standard ages is paramount to facilitate comparisons to ages determined using other chronometers, e.g., U-Pb, and to reduce systematic uncertainties. Both total fusion and incremental heating experiments on single crystals of the ACs and FCs were conducted and analyzed using a 5-collector Noblesse mass spectrometer. Single crystal incremental heating experiments are not reported by any of the recent standard calibrations using multi-collector mass spectrometers

74 (Phillips and Matchan, 2013; Gleadow et al., 2015; Rivera et al., 2011; 2013; Coble et al., 2011). Our

75 findings suggest that ACs remains a viable Quaternary ${ }^{40} \mathrm{Ar} /{ }^{39} \mathrm{Ar}$ standard, whereas isotopic heterogeneity 76 in the FCs makes it a non-ideal standard for high-precision timescale studies or chronometer calibrations.

\section{Instrumentation}

The Nu instruments Noblesse multi-collector mass spectrometer in the WiscAr laboratory at the

80 University of Wisconsin-Madison (model NG022) is equipped with a $75^{\circ}$ magnetic sector, Nier-type ion-

81 source, two quadrupole lens arrays, and a fixed collector block (i.e., no moving parts). Volume of the 
WiscAr Noblesse is $\sim 2300 \mathrm{cc}$. The collector configuration features an axial faraday detector and four discrete dynode $\mathrm{ETP}^{\circledR}$ ion-counting electron multipliers, two on the high mass side (IC0 and IC1) and two on the low mass side (IC2 and IC3), which allow for simultaneous measurement of all isotopes of Ar.

The ability of the instrument to resolve interferences is described by the mass resolving power (MRP), which is defined as $\mathrm{m} / \Delta \mathrm{m}$, where $\mathrm{m}$ is the mass of the peak and $\Delta \mathrm{m}$ is the mass difference

87 between 5\% and 95\% of peak height on the side of the peak (Ireland, 2013). The MRP of the WiscAr Noblesse is $\sim 3000$, which is considerably higher than that determined in most Noblesse instruments installed prior to 2015 (more recent instruments exceed this MRP; Saxton, 2015). The MRP of the WiscAr Noblesse allows for resolution of hydrocarbons from $\mathrm{Ar}$ at m/e 37 to 40 ; at m/e $36,{ }^{36} \mathrm{Ar}+\mathrm{H}^{35} \mathrm{Cl}$ can be substantially resolved from combined ${ }^{36} \mathrm{Ar}+\mathrm{H}^{35} \mathrm{Cl}+{ }^{12} \mathrm{C}_{3}$ (Fig. 1). To avoid any influence of ${ }^{12} \mathrm{C}_{3}$ at $\mathrm{m} / \mathrm{e} 36$ as well as other isobaric interferences at the other masses, measurements are taken on the low mass side of the argon peaks (Fig. 1). Peak position, width, and shape are optimized by first adjusting the source parameters and then changing the voltages of the quadrupole lenses. The same quadrupole settings are used for measurements of blanks, standard gas, and samples. All analyses in this study were conducted under similar high mass-resolution conditions.

The Noblesse is attached to a gas extraction line with a Photon Machines, Fusions $10.660 \mathrm{~W} \mathrm{CO}_{2}$ laser, two SAES GP-50 getters, an ARS cryotrap operating at $-125^{\circ} \mathrm{C}$, and two gas reservoir/pipette systems. Most analyses conducted are fusions of small mass single sanidine crystals or incremental heating of single sanidine crystals and small aliquots $(<20 \mathrm{mg})$ of volcanic groundmass. For total fusion experiments, the sample is melted in a single step at $\sim 6-7 \mathrm{~W}$ of laser power for $30 \mathrm{sec}$. Gas released from both fusion and incremental heating experiments is cleaned with two SAES GP50 getters, one at $50 \mathrm{~W}$ and one at room temperature, for 120 seconds followed by exposure to the cryotrap for an additional 60 seconds. Blank and standard gas analyses follow the same gas cleanup routine. Typical analytical blanks are $2500 \mathrm{cps}$ for ${ }^{40} \mathrm{Ar}$, $40 \mathrm{cps}$ for ${ }^{39} \mathrm{Ar}, 20 \mathrm{cps}$ of ${ }^{37} \mathrm{Ar}$, and $13-15 \mathrm{cps}$ for ${ }^{36} \mathrm{Ar}$ (Fig. 1); these approximately translate to $2.5 \mathrm{e}^{-17}$ moles of ${ }^{40} \mathrm{Ar}, 4.0 \mathrm{e}^{-19}$ moles of ${ }^{39} \mathrm{Ar}, 2.0 \mathrm{e}^{-19}$ moles of ${ }^{37} \mathrm{Ar}$, and $1.4 \mathrm{e}^{-19}$ moles of ${ }^{36} \mathrm{Ar}$ based on our estimate of instrument sensitivity. 


\section{Detector linearity}

One major limitation of ion-counting electron multipliers is that they are not suited to measure

111 large ion beams. Repeated bombardment with ion beams $>500,000$ cps degrades IC detectors over time,

112 which requires periodic increase of the voltage applied to the dynode so that it can operate in its plateau

113 region. There is a finite voltage range over which the collector can be operated, and once the maximum

114 collector voltage is reached, it must be replaced. Large ion beams also often result in non-linear behavior

115 of IC detectors (Hoffmann et al., 2005). An IC detector should measure a constant ratio of two isotopes

116 regardless of signal size, provided the detectors respond linearly to input ions and the dead time

117 correction is appropriate. We did not determine the dead time experimentally, but instead employed the

118 isotope ratio approach (e.g., Nelms et al., 2001; Nygren et al., 2011) to evaluate if the instrument dead

119 time setting in the IC0 and IC1 collectors is at an optimum value, and to determine at what signal sizes

120 the instrument dead time setting is no longer appropriate. We measured atmospheric Ar in single

121 collector mode over a range of signal sizes from 50,000 to 875,000 cps (Fig. 2). The intensity range

122 brackets typical ${ }^{40} \mathrm{Ar}$ and ${ }^{39} \mathrm{Ar}$ signals of sample unknowns. For both IC0 and IC1 detectors, the blank

123 corrected ${ }^{40} \mathrm{Ar} /{ }^{36} \mathrm{Ar}$ ratio was plotted against the measured ${ }^{40} \mathrm{Ar}$ intensity (Fig. 2). Both detectors are

124 linear over a very large dynamic range. The slope of the line fit through the data from 50,000 to $\sim 630,000$

125 cps is essentially horizontal (slope -7e-7). When the data from 700,000 to 750,000 cps is included, the

126 slope of the line through the data changes by nearly a factor of 3 , and thus the instrument dead time

127 setting is likely no longer appropriate. At 875,000 cps, counts are undoubtedly missed by the IC0 and

128 IC1 detectors, resulting in lower measured ${ }^{40} \mathrm{Ar} /{ }^{36} \mathrm{Ar}$ ratios (Fig. 2). Based on the results of this linearity

129 test, we established a gas splitting routine for signals $>630,000 \mathrm{cps}$, which includes a blank routine that

130 mimics the valve sequence of the gas splitting routine. For the IC2 and IC3 low mass IC detectors, which

131 typically do not exceed 50,000 cps of ${ }^{37} \mathrm{Ar}$ and $2000 \mathrm{cps}$ of ${ }^{36} \mathrm{Ar}$, respectively, the instrument dead time

132 correction for these relatively small signals is likely accurate. 


\section{Multi-collector calibration}

\subsection{Standard gas composition}

For decades, atmospheric Ar, specifically its ${ }^{40} \mathrm{Ar} /{ }^{36} \mathrm{Ar}$ ratio, has been routinely measured by

137 single collector mass spectrometers outfitted for ${ }^{40} \mathrm{Ar} /{ }^{39} \mathrm{Ar}$ analyses to assess any mass-dependent bias

138 introduced in the ion source or collectors. Coble et al. (2011) outline difficulties in using atmospheric Ar

139 to calibrate source mass discrimination and efficiency contrasts of IC detectors using a 3- collector

140 Noblesse, although these challenges have been surmounted in other laboratories (Rivera et al., 2011;

141 Brumm et al., 2010; Campisano et al., 2014). Our approach to multi-collector calibration is similar to that

142 of Coble et al. (2011) in that we have developed an in-house standard gas to assess mass discrimination

143 and differences in efficiencies of the IC detectors. However, because the collector configuration of the

144 WiscAr Noblesse (4IC + 1 Faraday) is different than that at Stanford (3 IC + 1 Faraday; Coble et al.,

145 2011), we do not need four reference gases. For reasons detailed in section 4.2, we can simply rely on

146 one standard gas, which contains ${ }^{39} \mathrm{Ar}$ mixed with atmosphere. The ${ }^{39} \mathrm{Ar}$ was produced from fusion of

147 grams of irradiated $\mathrm{Fe}$-doped $\mathrm{KAlSiO}_{4}$ glass. The ${ }^{39} \mathrm{Ar}$ released from the $\mathrm{K}$-glass was gettered for one

148 hour using the SAES getters on the gas extraction manifold and then exposed to the cryotrap, before

149 expansion into a $5 \mathrm{~L}$ reservoir containing atmospheric $\mathrm{Ar}$ that is behind a $0.1 \mathrm{cc}$ automated pipette. Our

150 determination of the isotopic composition of the standard gas was done in single collector mode with

151 measurements done on both the IC0 and IC1 detectors. Source mass bias was constrained via

152 measurements of atmospheric Ar in a blank-air-standard routine. The Lee et al. (2006) value for

153 atmospheric Ar was used for standard gas calibration. Standard gas calibration was conducted on both

154 the IC0 and IC1 detectors and measurements were performed periodically over a span of 18 months (Fig.

155 3). The ${ }^{40} \mathrm{Ar} /{ }^{39} \mathrm{Ar},{ }^{39} \mathrm{Ar} /{ }^{36} \mathrm{Ar}$, and ${ }^{36} \mathrm{Ar} /{ }^{38} \mathrm{Ar}$ are all known to a precision of better than $0.7 \%$ (Fig. 4). The

156 standard gas shown in Figure 3 was used for Noblesse measurements made from 2012 through 2014,

157 which includes many of the measurements discussed herein. However, we developed a new standard gas

158 in February 2015 that has a different isotopic composition than its predecessor (Figs. 1B and 3).

\section{4.2. Detector bias correction factors}



routine involving one peak hop (Table 1). This single routine works for experiments on samples of all 162 ages, which is unlike the complicated, multiple analytical routines outlined by Coble et al. (2011) and 163 Kellett and Joyce (2014) that are dependent on signal size, type of gas analyzed, and sample age. During 164 initial measurement of the gas ${ }^{40} \mathrm{Ar}$ (IC0), ${ }^{39} \mathrm{Ar}$ (IC1), ${ }^{37} \mathrm{Ar}$ (IC2), and ${ }^{36} \mathrm{Ar}$ (IC3) are measured

165 simultaneously, followed by a peak jump of one atomic mass unit where ${ }^{39} \mathrm{Ar}$ (IC0), ${ }^{38} \mathrm{Ar}$ (IC1), and ${ }^{36} \mathrm{Ar}$ 166 (IC2) are measured. This two-step cycle, which takes 35 seconds, is repeated 15 times. The Faraday 167 detector is not used. Beam switching is achieved by varying the field of the mass spectrometer magnet 168 and with no adjustment to the quadrupole focusing lenses. The peak hop is necessary to obtain ${ }^{40} \mathrm{Ar} /{ }^{39} \mathrm{Ar},{ }^{36} \mathrm{Ar} /{ }^{39} \mathrm{Ar}$, and ${ }^{37} \mathrm{Ar} /{ }^{39} \mathrm{Ar}$ ratios, which are needed to 170 calculate the age of a sample (McDougall and Harrison, 1999). Accurate and reproducible age 171 determinations using a multi-collector mass spectrometer require that mass fractionation effects and the 172 relative efficiencies of the different detectors be well known. This is achieved by repeating a standard 173 bracketing routine. Analysis of bracketing standard gas aliquots allows the calculation of correction 174 factors, which incorporate mass discrimination of the source and detector, and detector efficiency. The $175{ }^{39} \mathrm{Ar} /{ }^{36} \mathrm{Ar}$ is corrected for instrument mass fractionation and detector efficiencies using the following 176 equation:

$$
\begin{aligned}
& \text { true }{ }^{39} \mathrm{Ar} /{ }^{36} \mathrm{Ar} \text { (unknown) }=\text { measured }{ }^{39} \mathrm{Ar} /{ }^{36} \mathrm{Ar} \text { (unknown) } /\left[\text { measured }{ }^{39} \mathrm{Ar} /{ }^{36} \mathrm{Ar} \text { (standard) } /\right. \text { true } \\
& { }^{39} \mathrm{Ar} /{ }^{36} \mathrm{Ar} \text { (standard)]. }
\end{aligned}
$$

181 The measured ${ }^{39} \mathrm{Ar} /{ }^{36} \mathrm{Ar}$ value for the standard represents the average of the two standard analyses that 182 bracket the sample unknown. The decay of ${ }^{39} \mathrm{Ar}$ since creation of the standard gas and removal of sample 183 from the reactor are taken into account in all of the calculations. 

measured in IC1, is corrected differently because there is no ${ }^{37} \mathrm{Ar}$ in the standard gas. In this case, ${ }^{36} \mathrm{Ar}$ is measured in IC2 and ${ }^{38} \mathrm{Ar}$ in IC1 in step 2 of the analytical routine so that:

The measured ${ }^{36} \mathrm{Ar} /{ }^{38} \mathrm{Ar}$ value for the standard represents the average of the two standard analyses

192 that bracket the sample unknown. The correction of ${ }^{37} \mathrm{Ar}_{\mathrm{IC} 2} /{ }^{39} \mathrm{Ar}_{\mathrm{IC} 1}$ using ${ }^{36} \mathrm{Ar}_{\mathrm{IC} 2} /{ }^{38} \mathrm{Ar}_{\mathrm{IC} 1}$ works even when

$193{ }^{39} \mathrm{Ar}_{\mathrm{IC} 1}$ signals are appreciably larger than the ${ }^{38} \mathrm{Ar}_{\mathrm{IC} 1}$ signals. We recognize that this correction assumes

194 that the mass fractionation between ${ }^{37} \mathrm{Ar}$ and ${ }^{39} \mathrm{Ar}$ is the same as that between ${ }^{36} \mathrm{Ar}$ and ${ }^{38} \mathrm{Ar}$. It should

195 also be noted that a breakdown of the sources of analytical uncertainty assigned to each date in this study

196 indicate that the uncertainty associated with ${ }^{37} \mathrm{Ar}_{\mathrm{IC} 2} /{ }^{39} \mathrm{Ar}_{\mathrm{IC} 1}$ only contributes on average about $0.6 \%$ to the

197 analytical uncertainty versus $\sim 9.3 \%$ for ${ }^{40} \mathrm{Ar}_{\text {IC0 }} /{ }^{39} \mathrm{Ar}_{\text {IC } 0}$ uncertainty and $\sim 90.1 \%$ for ${ }^{36} \mathrm{Ar}_{\text {IC3 }} /{ }^{39} \mathrm{Ar}_{\text {IC1 }}$

198 uncertainty.

199 Because both ${ }^{40} \mathrm{Ar}$ and ${ }^{39} \mathrm{Ar}$ are measured in the same detector (IC0), the mass fractionation 200 correction required to convert measured $\left({ }^{40} \mathrm{Ar} /{ }^{39} \mathrm{Ar}\right)_{\mathrm{IC} 0}$ to the true $\left({ }^{40} \mathrm{Ar} /{ }^{39} \mathrm{Ar}\right)_{\mathrm{IC} 0}$ is ignored following

201 Brumm et al. (2010), who point out that the effect of this is a small systematic error, but because both 202 monitor and unknown minerals are handled in the same way, the effect cancels out when the ages for the 203 unknowns are calculated. All of the correction factors can vary by up to 2-3 per mil over a 24 hour 204 period. However, the variation is typically gradual, and thus is accurately captured by the standard analyses which are done every 45 minutes. Apart from the dead time correction, which is applied within the Noblesse software, all data reduction (including signal vs. time fits) and corrections (e.g., IC dark

207 noise, ${ }^{37} \mathrm{Ar}$ and ${ }^{39} \mathrm{Ar}$ decay, etc) are carried out offline using an in-house data reduction program. 


\section{Samples and results}

\subsection{Alder Creek rhyolite sanidine (ACs)}

Turrin et. al. (1994) proposed that sanidine from the rhyolite of Alder Creek be used as a

212 Quaternary standard for the ${ }^{40} \mathrm{Ar} /{ }^{39} \mathrm{Ar}$ method, in part because this rock has a transitional direction of 213 magnetization associated with the Cobb Mountain subchron, a period of normal polarity within the 214 Matuyama reversed chron that is recorded globally in marine sediments. Thus, the rhyolite of Alder 215 Creek is an important tie point of for the Geomagentic Instability Timescale (GITS; Singer, 2014). The 216 most commonly used age for ACs is that of Nomade et al. (2005), which is based on 225 single and 217 multi-crystal total fusion analyses that give a weighted mean of $1.1929 \pm 0.0007 \mathrm{Ma}$ ( $95 \%$ confidence 218 interval) relative to a Fish Canyon sanidine standard (FCs) age of 28.02 Ma. The Nomade et al. (2005) 219 age recalculates to $1.2006 \pm 0.0007 \mathrm{Ma}$ (Fig. 4), if using a FCs age of 28.201 Ma (Kuiper et al., 2008) 220 (Note: all ACs ages herein will be presented relative to a Fish Canyon sanidine standard age of 28.201 221 Ma using the Min et al. (2000) decay constant with analytical uncertainties only at the 95\% confidence interval unless specified otherwise). Many ${ }^{40} \mathrm{Ar} /{ }^{39} \mathrm{Ar}$ laboratories have attempted to independently determine the age of ACs relative to another standard. The EARTHTIME experiment to inter-calibrate

224 laboratories against one another by measuring the isotopic composition of ACs relative to the FCs 225 standard yielded variable results with ACs ages spanning 3\% (gray field in Fig. 4; Heizler and 226 EARTHTIME working group, 2008). Several recent attempts to determine the age of ACs using multi227 collector mass-spectrometers yield consistent results, despite using different collector calibration routines. 228 Rivera et al. (2013) report that 75 of 88 single crystal fusions of ACs-2, the same sample analyzed by 229 Nomade et al. (2005), give a weighted mean ${ }^{40} \mathrm{Ar} /{ }^{39} \mathrm{Ar}$ age of $1.1864 \pm 0.0006 \mathrm{Ma}$. Coble et al. (2011) 230 present nine dates with an imprecise weighted mean of $1.1877 \pm 0.0068 \mathrm{Ma}$. The youngest $28{ }^{40} \mathrm{Ar} /{ }^{39} \mathrm{Ar}$ 231 dates of Phillips and Matchan (2013) give a weighted mean of $1.1847 \pm 0.0006 \mathrm{Ma}$, although this 232 population has a MSWD of 2.7 (Fig. 4). It is important to note that Phillips and Matchan (2013) fused 2-

2333 crystals per analysis, whereas all the other previously mentioned studies performed single crystal 234 fusions. 
to determine the age of the Alder Creek sanidine. All experiments were performed on the ACs-2

standard, which is a split of the same sample analyzed by Nomade et al. (2005) and Rivera et al. (2013).

Total fusion dates span $19 \mathrm{ka}$ or $\sim 1.6 \%$ from $1.178 \pm 0.003 \mathrm{Ma}$ to $1.197 \pm 0.003 \mathrm{Ma}$, which is similar to the range observed by Rivera et al. (2013) and Phillips and Matchan (2013). Thirty-eight of 51 dates give a weighted mean of $1.1865 \pm 0.0004$ Ma with a MSWD of 0.86 (Fig. 4). Most grains of ACs are highly radiogenic with ${ }^{40} \mathrm{Ar} *$ typically greater than $90 \%$, but about one-third of the analyzed sanidine had 79 $90 \%{ }^{40} \mathrm{Ar} *$. There are tails of ${ }^{40} \mathrm{Ar} /{ }^{39} \mathrm{Ar}$ dates to both the young and old ends of the mean population of 41

243 dates. A similar trend was observed by Rivera et al. (2013). There is no obvious correlation between age, $244 \mathrm{~K} / \mathrm{Ca}$ ratio, ${ }^{40} \mathrm{Ar}^{*}$, or signal size.

The recent development of new generation noble gas mass spectrometers has facilitated considerable focus on improving the precision and accuracy of ${ }^{40} \mathrm{Ar} /{ }^{39} \mathrm{Ar}$ ages, most of which centers on the ${ }^{36} \mathrm{Ar}$ measurements (e.g., Saxton, 2015). Whereas the measurement of ${ }^{36} \mathrm{Ar}$ is critical, especially given the complexities that can now be resolved at m/e 36 (Fig. 1), much of the improved precision obtained using multi-collector mass spectrometers is simply due to improved counting statistics for ${ }^{40} \mathrm{Ar}$ and ${ }^{39} \mathrm{Ar}$.

250 Figure 5 compares results from Alder Creek sanidine analyzed using: (1) the MAP 215-50 and (2)

251 Noblesse mass spectrometers in the WiscAr laboratory, and (3) an Argus VI mass spectrometer (Phillips 252 and Matchan, 2013). Compared to the modest reduction in the uncertainty of the ${ }^{36} \mathrm{Ar}$ intercept when 253 using the Noblesse or Argus VI, uncertainties associated with the ${ }^{40} \mathrm{Ar}$ and ${ }^{39} \mathrm{Ar}$ intercepts are reduced by 254 a factor of 5-6 using the Noblesse relative to the single-collector MAP 215-50 instrument. Single crystal incremental heating experiments of ACs-2 were performed as part of an 256 interlaboratory comparison between the WiscAr laboratory, New Mexico Tech, and Oregon State 257 University (Heizler et al., 2015). Nineteen of 26 crystals analyzed using the Noblesse produced plateau 258 ages (73\% success rate). Our criteria for an acceptable plateau are similar to those outlined by Sharp and 259 Renne (2005) and Jicha et al. (2012). The youngest 13 plateau ages have a weighted mean of $1.1861 \pm$ $2600.0006 \mathrm{Ma}$, nearly identical to the weighted mean fusion age. Interestingly, none of the 19 plateau ages 
are younger than $1.1847 \pm 0.0017 \mathrm{Ma}$, but six are slightly older, extending to $1.1951 \pm 0.0019 \mathrm{Ma}$. The

262 origin of the older dates is unclear, but may reflect antecrysts mobilized during eruption of the Alder

263 Creek rhyolite or a uniform distribution of excess Ar during the incremental heating experiment. The

264 integrated ages of the 19 crystals that yielded plateaus span $1.1757 \pm 0.0017$ Ma to $1.1957 \pm 0.0019$,

265 nearly identical to the range exhibited by the total fusions. The first step of numerous incremental heating

266 experiments is distinctly younger than the plateau age, which could explain why several total fusion and

267 integrated ages are younger than the youngest plateau ages.

\subsection{Fish Canyon Tuff sanidine (FCs)}

Sanidine from the Fish Canyon tuff was first proposed as a ${ }^{40} \mathrm{Ar} /{ }^{39} \mathrm{Ar}$ standard by Cebula et al.

271 (1986). It is the most widely used ${ }^{40} \mathrm{Ar} /{ }^{39} \mathrm{Ar}$ mineral standard (Renne et al., 1998), yet its age remains the

272 subject of scrutiny. The FCs age currently used by ${ }^{40} \mathrm{Ar} /{ }^{39} \mathrm{Ar}$ laboratories ranges from 27.64 to 28.29 Ma

273 (Hildreth et al., 2014; Renne et al., 2011). ${ }^{238} \mathrm{U} /{ }^{206} \mathrm{~Pb}$ zircon dates from the Fish Canyon Tuff vary from

27428.0 to 28.6 Ma (e.g. Schmitz and Bowring, 2001; Bachmann et al., 2007; Rivera et al., 2011; Wotzlaw et

275 al., 2013). Notably, Wotzlaw et al. (2013) used the CA-ID-TIMS method to determine ${ }^{238} \mathrm{U} /{ }^{206} \mathrm{~Pb}$ dates

276 from 24 individual zircons in the Fish Canyon tuff, finding that zircon records crystallization of the

277 magma body for $442 \mathrm{kyr}$ ending with the youngest zircon measured at $28.196 \pm 0.038 \mathrm{Ma}$ ( $2 \sigma$ analytical).

278 Several studies over the last five years have attempted to reduce the systematic uncertainties associated

279 with the ${ }^{40} \mathrm{Ar} /{ }^{39} \mathrm{Ar}$ method by calibrating the age of FCs. Kuiper et al. (2008) cross-calibrated ${ }^{40} \mathrm{Ar} /{ }^{39} \mathrm{Ar}$

280 sanidine ages from tephras in the astronomically tuned Messâdit section (Melilla Basin, Morocco) to

281 determine the age of FCs as $28.201 \pm 0.012 / 0.046 \mathrm{Ma}(2 \sigma$, analytical/external). Rivera et al. (2011) used

282 a similar technique to cross calibrate A1 tephra sanidines (A1Ts) of the astronomically tuned Faneromeni

283 section (Crete), resulting in an FC age of 28.172 $\pm 0.018 / 0.028 \mathrm{Ma}(2 \sigma$, analytical/external). Renne et al.

$284(2010,2011)$ used a different approach to obtain a FCs age of $28.294 \pm 0.072 \mathrm{Ma}(2 \sigma$, external) by jointly

285 determining the ${ }^{40} \mathrm{Ar} * /{ }^{40} \mathrm{~K}$ for FCs and ${ }^{40} \mathrm{~K}$ decay constants based on published ${ }^{40} \mathrm{~K}$ activity and ${ }^{40} \mathrm{Ar} /{ }^{39} \mathrm{Ar}$ 
$286+{ }^{238} \mathrm{U} /{ }^{206} \mathrm{~Pb}$ data pairs (Renne et al., 2011). The Kuiper et al. (2008) FCs age is indistinguishable at $2 \sigma$

287 from the astronomically calibrated FCs age of Rivera et al. (2013), the FCs age of Renne et al. (2011),

288 and the youngest zircon in the Fish Canyon Tuff dated by Wotzlaw et al. (2013). Two recent studies used

289 the Argus VI multi-collector mass spectrometer with Faraday detectors at Melbourne University to

290 produce FCs ages that are significantly more precise than each of the previously published FCs ages.

291 Phillips and Matchan (2013) performed 30 laser fusions on 2-4 crystal aliquots and obtained an age of

$29228.201 \pm 0.005 \mathrm{Ma}$, whereas 10 single crystal fusions of Gleadow et al. (2015) give a slightly younger

293 FCs age of $28.185 \pm 0.009$ Ma. Both of the Melbourne University FCs datasets used Fish Canyon

294 sanidine as the fluence monitor, and therefore cannot truly be used to assess the age of FCs. mass-spectrometer yield ${ }^{40} \mathrm{Ar} /{ }^{39} \mathrm{Ar}$ dates that span $88 \mathrm{ka}$ and have a MSWD of 3.6. This aliquot of FCs

297 was monitored with the 1.186 Ma Alder Creek sanidine standard (Rivera et al., 2013) and is from a

298 different irradiation than the one used to determine the age of the Alder Creek sanidine standard (Figure

299 4). All FCs used in this study come from the split FC-2, which was collected in 1994, separated, and

300 distributed by New Mexico Tech. The average uncertainty on the individual FCs dates using the Noblesse

301 is $\pm 30 \mathrm{ka}$. FCs dates with smaller uncertainties of \pm 10 ka have been obtained using an Argus VI mass

302 spectrometer because the ${ }^{40} \mathrm{Ar}$ signal can be directed into a Faraday detector (Heizler, 2012), whereas the

$303{ }^{40} \mathrm{Ar}$ signals for the IC0 collector of the Noblesse are limited to $\sim 650,000 \mathrm{cps}$ (Fig. 3). In an attempt to

304 understand the age dispersion among the fusion results, we incrementally heated 16 single FCs crystals

305 from two different irradiations. One aliquot of FCs was monitored with the 28.52 Ma Taylor Creek

306 sanidine standard and the other was monitored with FCs itself. We recognize that by monitoring FCs

307 with FCs and Taylor Creek sandine, whose age has been determined relative to Fish Canyon sanidine

308 (Renne et al., 1998), we cannot weigh in the ongoing debate as to which FCs age calibration is the most

309 accurate. In order to independently determine the age of FCs, one needs to measure FCs as an unknown

310 against a standard whose age has been independently established by other means as in the case of the 
311 astronomically dated $6.943 \pm 0.005 \mathrm{Ma}(2 \sigma)$ A1 tephra (A1Ts; Kuiper et al., 2004; Rivera et al., 2011) an

312 astronomically-calibrated ${ }^{40} \mathrm{Ar} /{ }^{39} \mathrm{Ar}$ standard such as the and Alder Creek sanidine (Rivera et al., 2013), or

313 a primary standard such as GA-1550 biotite (Renne et al., 1998).

314 Only six of the 16 single crystal incremental heating experiments gave a statistically acceptable

315 age plateau (37.5\% success rate compared to $73 \%$ for the ACs) (Fig. 6). A weighted mean age of these 6

316 plateaus is $28.186 \pm 0.008 \mathrm{Ma}$, which is nearly identical to the weighted mean age of Gleadow et al.

317 (2015) of $28.185 \pm 0.009$ Ma. Several of our single crystal incremental heating experiments produced

318 saddle shaped or rising gas release patterns, similar to the multi-crystal (10-25 crystals) experiments

319 reported in Phillips and Matchan (2013) and Gleadow et al. (2015) (Fig. 7). The integrated ages for the

320 sanidine grains that did not form a plateau are both younger and older than the six plateau ages and span a

321 larger range than that observed during the total fusions. Most of the integrated ages are older than 28.2

322 Ma (Fig. 6), and may reflect the incorporation of excess Ar into the crystal structure.

\subsection{Lava Creek Tuff sanidine}

In addition to investigating the ages and argon systematics of commonly used ${ }^{40} \mathrm{Ar} /{ }^{39} \mathrm{Ar}$ standards,

326 we evaluate the ages of key marker horizons from supereruptions in the western U.S. The Lava Creek

327 Tuff $\left(>1000 \mathrm{~km}^{3}\right)$ is the youngest of the three Yellowstone caldera-forming supereruptions. Christiansen

328 (2001) identified two Lava Creek Tuff members, A and B, which are separated from each other by a bed

329 of fallout. Proximal member B ignimbrite is comparable in volume to member A, but the distal B tephra

330 blanketed much of the central and western United States. Its occurrence in numerous sedimentary and

331 pluvial lake bed sequences makes it a key Quaternary chronostratigraphic marker.

The Lava Creek Tuff member B sample was collected by Tiffany Rivera from a road cut along

333 state highway 47, south of the Lower Mesa Falls turn off $\left(44^{\circ} 08.446,-111^{\circ} 17.405,1760 \mathrm{~m}\right)$. It

334 corresponds to the sample site of Bindeman et al. (2001) and is from the more densely welded part of the

335 unit. The sample is light gray to purple with large phenocrysts of sanidine (3-5 $\mathrm{mm})$ and quartz (1-3 mm). 
Pumice distribution within the unit is somewhat bimodal, with typical pumice lengths being $\sim 1 \mathrm{~cm}$ or 5$10 \mathrm{~cm}$, all of which are flattened such that the length to width ratio is 10:1. Lanphere et al., 2002) from the Lava Creek Tuff members A and B yield dates ranging from 560 to 700 ka. A recent study by Matthews et al (2015) found that Lava Creek Tuff member B sanidine yielded a unimodal population of 66 single crystal ${ }^{40} \mathrm{Ar} /{ }^{39} \mathrm{Ar}$ dates with a weighted mean of $634.0 \pm 2.9 / 3.7 \mathrm{ka}$, and an isochron date of $631.9 \pm 3.5 / 4.3 \mathrm{ka}$. The ${ }^{40} \mathrm{Ar} /{ }^{36} \mathrm{Ar}$ intercept of the isochron is higher than, albeit barely overlapping with the atmospheric value when considering the associated uncertainties, thereby suggesting

344 the presence of excess argon. Thirteen of $15 \mathrm{CA}-\mathrm{ID}-\mathrm{TIMS} \mathrm{U}-\mathrm{Pb}$ zircon dates from Lava Creek B give a weighted mean of $629.2 \pm 4.3 \mathrm{ka}$ (Wotzlaw et al., 2015).

Analyses of 24 single crystal sanidine fusions from Lava Creek Tuff member B using the

347 Noblesse give dates ranging from $627.8 \pm 7.0 \mathrm{ka}$ to $685.2 \pm 13.7 \mathrm{ka}$ (Fig. 8; Rivera and Jicha, 2015), which is consistent with previous single crystal fusion data (Gansecki et al., 1998; Matthews et al., 2015).

349 The youngest 11 dates have a weighted mean age of $630.9 \pm 1.2 / 2.7 \mathrm{ka}$, which we interpret as our best estimate of the eruptive age. The $630.9 \pm 1.2 / 2.7 \mathrm{ka}$ age is within error of the $634.0 \pm 2.9 / 3.7 \mathrm{ka}{ }^{40} \mathrm{Ar} /{ }^{39} \mathrm{Ar}$ age of Matthews et al. (2015) and the U-Pb age of $629.2 \pm 4.3 \mathrm{ka}$ age of Wotzlaw et al. (2015). It is important to note that the Matthews et al. (2015) age is slightly older because their weighted mean age includes dates that they suggest come from crystals that contain excess argon. However, because the dates generated by the Noblesse have significantly smaller analytical uncertainties (average of $\pm 6 \mathrm{ka}$ ) than those of the Matthews et al. (2015) (average of $\pm 28 \mathrm{ka}$ ), we are able to exclude dates that are as little as $8 \mathrm{ka}$ older (i.e., $638.6 \pm 4.7 \mathrm{ka}$ ) than the youngest mean group of dates $(630.9 \pm 1.2 \mathrm{ka})$. Single crystal incremental heating is required in order to determine whether the older dates reflect crystals that contain excess argon or are antecrysts such as those found in the Huckleberry Ridge Tuff (Singer et al., 359 2014). 
The distal ash falls from four voluminous eruptions near the Cenomanian-Turonian boundary (ca. $94 \mathrm{Ma})$ are preserved as bentonites that can be traced through much of the western interior of the United States (Elder, 1988). Bentonite marker bed B is the largest and most widely traceable of these four marker horizons, with deposits found in at least 11 U.S. states and in Alberta, Canada (Elder, 1988). It was deposited during the heavy carbon isotopic excursion termed Ocean Anoxic Event 2 (Schlanger and Jenkyns, 1976) within the Neocardioceras juddii ammonite biozone. The isopach map of bed B suggests a source area near the U.S.-Canada border in the region of northeastern Washington/northwestern Montana (Elder, 1988). Although the B bentonite is $\sim 90 \mathrm{~cm}$ near the Montana border, it is $135 \mathrm{~cm}$ thick in the Alberta foothills, which suggests origin from a source further north (Barker et al., 2011). We analyzed sanidine from samples K-07-01B (Meyers et al., 2012) and 90-O-19 (Meyers et al., 2012; Obradovich, 1993). K-07-01B corresponds to Bed 80 from GSSP type locality in Pueblo, CO 373 (Kennedy et al., 2005) and was collected by B. Sageman \& D. Condon. Sample 90-O-19 is a 15-20 cm white bentonite from Thayer County, Nebraska that corresponds to sample location 20 in Obradovich (1993). Eighteen single sanidine fusions of K07-01B give dates ranging from 93.74 \pm 0.11 Ma to $94.72 \pm$ 0.08 Ma (Fig. 9; Supplementary material). The oldest three and youngest two dates are excluded from this group because they have a normalized median absolute deviation (nMAD) greater than 1.5 and are considered outliers (Powell et al., 2002). The weighted mean age of the remaining 13 dates is $93.99 \pm$ $0.03 \mathrm{Ma}$ (Fig. 9). For 90-O-19, 13 of 16 dates give a weighted mean age of $93.98 \pm 0.03 \mathrm{Ma}$, which is nearly identical to our new ${ }^{40} \mathrm{Ar} /{ }^{39} \mathrm{Ar}$ age of K07-01B and within error of the single and multi-crystal fusion ${ }^{40} \mathrm{Ar} /{ }^{39} \mathrm{Ar}$ ages of $94.10 \pm 0.37 \mathrm{Ma}$ and $94.07 \pm 0.31 \mathrm{Ma}$ from Meyers et al. (2012) for K07-01B and 90-O-19, respectively. Meyers et al. (2012) suggested that the U-Pb age of 94.01 $\pm 0.04 / 0.14 \mathrm{Ma}$ from the B bentonite in Thayer County, Nebraska (sample site NE-08-01 =90-O-19) is the most accurate 384 estimate of time since eruption, whereas the K-07-01B sample contains a large proportion of inherited 385 zircons. The U-Pb age of $94.01 \pm 0.04 / 0.14 \mathrm{Ma}$ is in good agreement with the new high precision $386{ }^{40} \mathrm{Ar} /{ }^{39} \mathrm{Ar}$ age of $93.99 \pm 0.03 / 0.22 \mathrm{Ma}$ and $93.98 \pm 0.03 / 0.22 \mathrm{Ma}$ for the B bentonite. Interestingly, the 387 youngest zircon date of $94.01 \pm 0.17 / 0.23 \mathrm{Ma}$ from K07-01B is also in agreement with the new ${ }^{40} \mathrm{Ar} /{ }^{39} \mathrm{Ar}$ 
dates and the $\mathrm{U}-\mathrm{Pb}$ age from Nebraska. The new, high-precision age for the $\mathrm{B}$ bentonite based on the ${ }^{40} \mathrm{Ar} /{ }^{39} \mathrm{Ar}$ and the U-Pb ages from Colorado and Nebraska is 93.994 \pm 0.018/0.093 Ma. The Bighorn River bentonite in Alberta, Canada is interpreted to correlate with the B bentonite (Barker et al., 2011 and

391 references therein). A U-Pb age of 94.29 \pm 0.13/0.20 Ma (MSWD = 2.4) (Barker et al., 2011), based on

392 six zircon dates, is slightly older than our new, high-precision age if only analytical uncertainties are 393 considered. However, the youngest three zircons give an age of 94.14 $\pm 0.12 / 0.19 \mathrm{Ma}(\mathrm{MSWD}=0.55)$

394 that is within error of the high-precision ${ }^{40} \mathrm{Ar} /{ }^{39} \mathrm{Ar}$ age. ${ }^{40} \mathrm{Ar} /{ }^{39} \mathrm{Ar}$ ages with the precisions obtained using 395 the Noblesse now enable improved interpretation of the ranges of dates produced using CA-IDTIMS U$396 \mathrm{~Pb}$ zircon dating.

397 6. Discussion

\subsection{Age of the Alder Creek sanidine standard}

The Alder Creek sanidine has somewhat less age complexity when compared to the Fish Canyon sanidine age distributions (Figs. 4, 6). Incremental heating (IH) experiments of a few ACs crystals gave saddle shaped spectra like those observed by Phillips and Matchan (2013), but the majority of the IH experiments on single ACs crystals (73\%) yielded plateaus (Heizler et al., 2015). Despite the fact that the radiogenic ${ }^{40} \mathrm{Ar}$ yield can be variable and some of the crystals appear to contain excess Ar, the ACs

404 appears to be a viable Quaternary ${ }^{40} \mathrm{Ar} /{ }^{39} \mathrm{Ar}$ standard. Rivera et al. (2013) recommended use of a $405{ }^{40} \mathrm{Ar} /{ }^{39} \mathrm{Ar}$ age of $1.1864 \pm 0.0006 / 0.0016 \mathrm{Ma}$ (95\% confidence analytical/full external) for ACs, but this 406 has not been widely adopted. All of the recent single crystal age determinations of sanidine from the 407 rhyolite of Alder Creek (ACs) that employ multi-collector mass spectrometry including the findings of 408 Rivera et al. (2013) as well as both single crystal total fusion and incremental heating results presented 409 here, results in an age of $1.1864 \pm 0.0003 / 0.0012 \mathrm{Ma}(95 \%$ confidence analytical/full external). This age 410 should now serve as the preferred age for ACs because it is more accurate than the commonly used age of 411 Nomade et al. (2005), which more than $1 \%$ older. The origin of age discrepancy is unknown, but it is 412 likely related to analytical conditions during the Nomade et al. (2005) study. These may include 
413 inaccurate measurement of the ${ }^{36} \mathrm{Ar}$ blank and its ${ }^{40} \mathrm{Ar} /{ }^{36} \mathrm{Ar}$ ratio, or improper assignment of time zero, the 414 time at which the gas is expanded from the extraction system into the mass spectrometer.

415 The transitionally magnetized rhyolite of Alder Creek is the type locality for the Cobb Mountain 416 normal polarity subchron. Rivera et al. (2013) suggest that the astronomical ages of 1.173 and $1.185 \mathrm{Ma}$

417 for the Cobb Mountain subchron determined using the sediment record of Horng et al. (2002) are the most 418 accurate, and thus the Alder Creek rhyolite records the older reversal at the base of the subchron.

419 However, to our knowledge, there are no other known sediments or lavas globally, which potentially 420 record a 1.173 Ma reversal bounding the Cobb Mountain subchron. In cores from ocean drilling program 421 sites 983 and 984 in the North Atlantic Ocean characterized by high deposition rates, Channell et al. 422 (2002) found the Cobb Mountain subchron to be defined by abrupt polarity transitions at its base and top 423 associated with astronomical ages of 1.215 and 1.190 Ma, respectively. Moreover, the PISO-1500 stack 424 of Channell et al. (2009) that is based on 14 high resolution relative paleointensity and $\delta^{18} \mathrm{O}$ records 425 reveals that the Cobb Mountain subchron is associated with a 30 kyr period of exceptionally low intensity 426 between 1215 and $1185 \mathrm{ka}$. Thus, a $1.1864 \pm 0.0003 / 0.0012 \mathrm{Ma}$ age for ACs argues that the transitionally 427 magnetized rhyolite of Alder Creek records a snapshot of the younger reversal at the top of the Cobb 428 Mountain subchron, not the older reversal at its base (Singer, 2014). This is further supported by a 1.211 $429 \pm 0.011 \mathrm{Ma}$ age determined for a transitionally-magnetized lava flow at Persani Mountain, Romania that 430 is interpreted to record the reversal at the base of this subchron (Panaiotu et al., 2013). for prominent Quaternary eruptions are eliminated. For example, the age of the Bishop Tuff remains controversial as there are significant differences between published ${ }^{40} \mathrm{Ar} /{ }^{39} \mathrm{Ar}$ dates, ranging from $767.3 \pm$ 435 other chronometers including astrochronology (Zeeden et al., 2014), U-Pb ID-TIMS (Crowley et al., 436 2007; Ickert et al., 2015), and U-Pb SIMS (Chamberlain et al., 2014a; Ickert et al., 2015) favor a Bishop 437 Tuff eruption age of $\sim 763-773 \mathrm{ka}$, however, there are some assumptions associated with each of these 438 age determinations (see Ickert et al., 2015 for discussion). If the ${ }^{40} \mathrm{Ar} /{ }^{39} \mathrm{Ar}$ data of Simon et al. (2014) are 
recalculated using a 1.1864 Ma age for ACs and the Min et al. (2000) decay constant, their age for the

Bishop Tuff becomes $768 \pm 2 \mathrm{ka}$, which is in agreement with all other recent age determinations.

6.2 Age heterogeneity in the Fish Canyon sanidine

For reasons mentioned in section 5.2, the primary goal of our single crystal fusion and

444 incremental heating experiments of the FCs was not to arrive at an independent age for FCs, but rather to

445 evaluate its viability as a ${ }^{40} \mathrm{Ar} /{ }^{39} \mathrm{Ar}$ standard. However, our FCs used for the total fusion experiments was

446 monitored with the astronomically calibrated Alder Creek sanidine (Rivera et al., 2013). The youngest 10

447 fusions give a weighted mean age of $28.175 \pm 0.0011 \mathrm{Ma}$, which, at a first-order, (1) verifies the $28.172 \pm$

$4480.017 / 0.028 \mathrm{Ma}$ astronomical calibration of Rivera et al. (2011), (2) suggests that the $\mathrm{R}_{\mathrm{FC} / \mathrm{AC}}$ of the

449 Quadlab and WiscAr laboratory is nearly identical, and (3) indicates that the 28.294 Ma age

450 recommended by Renne et al. (2011) is too old. A much larger dataset set relative to an astronomically

451 calibrated standard is required to more quantitatively evaluate the age of FCs.

A comparison of the FCs spectra from our single crystal incremental heating experiments to those produced in several published multi-crystal step heating experiments (e.g., Spell and McDougall, 2003; Bachmann et al., 2007; Phillips and Matchan, 2013; Gleadow et al., 2015) indicates that the gas release patterns can be reproduced at the single grain level (Fig. 6). It should not come as a surprise that age complexity would be present in the in FCs because it comes from a voluminous ash-flow tuff associated with a supereruption. It is well known that silicic tuffs may contain alkali feldspars much older than their 458 deposional age, and that these reflect inheritance from older rocks at or below the earth's surface (e.g., 459 LoBello et al., 1987; Deino and Potts, 1992). Remarkably, advances in both $\mathrm{U}-\mathrm{Pb}$ and ${ }^{40} \mathrm{Ar} /{ }^{39} \mathrm{Ar}$ methods 460 have begun to reveal that many supereruption deposits contain not only ancient inherited xenocrysts, but 461 also antecrysts and remobilized, partly solidified, portions of magma chambers that include both sanidine 462 and zircon slightly older than the age of eruption (e.g., Chamberlain et al., 2014a,b; Rivera et al., 2014;

463 Wotzlaw et al., 2013). Renne et al. (2012) demonstrated that inherited ${ }^{40} \mathrm{Ar}$, such as that in antecrysts or 
remobilized roof rocks, can be retained in alkali feldspars despite immersion in magma at $\sim 900{ }^{\circ} \mathrm{C}$ for tens to $>100$ years, thereby offering a mechanism to explain some of the slightly older ages in the FCs. We concur with the conclusion of Phillips and Matchan (2013) that FCs is a non-ideal standard for high precision ${ }^{40} \mathrm{Ar} /{ }^{39} \mathrm{Ar}$ geochronology. Thus, an urgent short-term goal for the ${ }^{40} \mathrm{Ar} /{ }^{39} \mathrm{Ar}$ community must be to identify and calibrate a more reliable sanidine standard, preferably one from a distal airfall deposit or small-volume rhyolitic lava or dome of similar age to FCs. Accurate and precise determination of a new standard is needed because analytical uncertainties from multi-collector mass spectrometers are now significantly smaller than the full external uncertainties.

\subsection{Implications for the Cretaceous timescale}

As demonstrated by our sanidine total fusion data from the B bentonite of Elder (1988), we can now obtain ${ }^{40} \mathrm{Ar} /{ }^{39} \mathrm{Ar}$ dates from individual Cretaceous sanidine crystals with analytical uncertainties of $<0.03 \mathrm{Ma}$, which rival the uncertainties of the most precise ID-TIMS U-Pb zircon dates for this time period. One drawback of the new, high-precision ${ }^{40} \mathrm{Ar} /{ }^{39} \mathrm{Ar}$ data is that age distributions are more complex because dates often span a continuum (Fig. 9), like many of the ID-TIMS U-Pb zircon datasets. The practice of calculating a weighted mean eruptive age from a subgroup of the youngest crystals can be compromised due to the fact that some crystals may exhibit Ar loss. In some cases, there may not be a single "age" that can be gleaned from a distribution. What is clear is that rigorous statistical interrogation/filtering of high-precision ${ }^{40} \mathrm{Ar} /{ }^{39} \mathrm{Ar}$ and $\mathrm{U}-\mathrm{Pb}$ data are now required to identify an eruptive/depositional age. The greatly improved precision and accuracy of Cretaceous ${ }^{40} \mathrm{Ar} /{ }^{39} \mathrm{Ar}$ and $\mathrm{U}-\mathrm{Pb}$ ages now allow us to: (1) confirm or consider alternative correlations of some ash beds in the Western Interior Basin, specifically those of supereruptions with associated tephra fall deposits that span vast regions, (2) re-examine stratigraphic data to potentially identify previously obscured hiatuses, (3) precisely constrain sedimentation rates, and (4) anchor floating astronomical time scales for portions of the Cretaceous that have a resolving power better than the duration of a $100 \mathrm{kyr}$ eccentricity cycle and can thus be used to pinpoint rapid environmental fluctuations and biological changes. 


\section{Conclusions}

- The high mass resolving power of the Noblesse allows for partial resolution of ${ }^{36} \mathrm{Ar}+\mathrm{H}^{35} \mathrm{Cl}$ from $\mathrm{a}^{36} \mathrm{Ar}+\mathrm{H}^{35} \mathrm{Cl}+{ }^{12} \mathrm{C}_{3}$ sum peak at m/e 36, which is particularly significant for ${ }^{40} \mathrm{Ar} /{ }^{39} \mathrm{Ar}$ analyses of sanidine that only yield a few counts per second of ${ }^{36} \mathrm{Ar}$.

- We have calibrated a reference gas and developed a simple analytical routine involving one peak hop, both of which are used to evaluate detector-bias correction factors that include mass dependent fractionation in the source and detector as well as detector efficiency.

- Single crystal age determinations of sanidine from the rhyolite of Alder Creek (ACs) that employ multi-collector mass spectrometry including the findings of Rivera et al. (2013) and both single crystal total fusion and incremental heating results presented here, favor an age of $1.1864 \pm$ 0.0003/0.0012 Ma (95\% confidence analytical/full external). This age should now serve as the preferred age for ACs because it is more accurate than the commonly used age of Nomade et al. (2005), which is more than $1 \%$ older.

- Multi-collector mass spectrometers, including the WiscAr Noblesse instrument, have led to nearly an order of magnitude improvement in analytical precision relative to traditional singlecollector instruments. Independent studies using different multi-collector instruments demonstrate age heterogeneity in the Fish Canyon sanidine standard, the most widely used neutron fluence monitor in the ${ }^{40} \mathrm{Ar} /{ }^{39} \mathrm{Ar}$ community. Only a small percentage of the incrementally heated single crystals yield an age plateau, and most appear to be affected by Ar loss or contain excess Ar. These characteristics are obviously not ideal for $\mathrm{a}^{40} \mathrm{Ar} /{ }^{39} \mathrm{Ar}$ dating standard, and we suggest that use of FCs in ${ }^{40} \mathrm{Ar} /{ }^{39} \mathrm{Ar}$-based refinement of the geologic timescale or calibration of other chronometers must be done with caution. capable of distinguishing antecrysts and xenocrysts from juvenile crystals at the $1 \%$ level of 

whose daughter diffusion closure temperature is much lower than in zircon - can provide both temporal and thermal constraints useful in leveraging the interpretation of U-Pb ID-TIMS zircon

\section{Acknowledgements}

522 We thank John Saxton at Nu Instruments for technical assistance and advice, and Dave Phillips for 523 sharing Argus VI data. Tiffany Rivera supplied useful comments on an earlier version of the manuscript.

524 Constructive comments by Matt Heizler and an anonymous reviewer are appreciated. The Noblesse mass spectrometer was purchased with funds from the NSF Instrumentation and Facilities Program (EAR0741794). This work was further supported by NSF grants EAR-0959108, and -1250446.

\section{References}

Bachmann, O., Oberli, F., Dungan, M.A., Meier, M., Mundil, R., Fischer, H., 2007. ${ }^{40} \mathrm{Ar}{ }^{39} \mathrm{Ar}$ and U-Pb dating of the Fish Canyon magmatic system, San Juan Volcanic field, Colorado: evidence for an extended crystallisation history. Chemical Geology 236, 134-166.

Barker, I.R., Moser, D.E., Kamo, S.L., Plint, A.G., 2011. High-precision U-Pb zircon ID-TIMS dating of two regionally-extensive bentonites: Cenomanian stage, Western Canada Foreland Basin: Canadian Journal of Earth Sciences 48, 543-556, doi:10.1139/E10-042.

Bindeman, I.N., Valley, J.W., 2001. Low- $\delta^{18}$ O rhyolites from Yellowstone: magmatic evolution based on analyses of zircons and individual phenocrysts. Journal of Petrology 42, 1491-1517.

Brumm, A., Jensen, G.M., van den Bergh, G.D., Morwood, M.J., Kurniawan, I., Aziz, F., Storey, M., 2010. Hominins on Flores, Indonesia, by one million years ago. Nature 464, 748-752.

Campisano, C.J., Kirk, E.C., Townsend, K.E.B., Deino, A.L., 2014. Geochronological and Taxonomic Revisions of the Middle Eocene Whistler Squat Quarry (Devil's Graveyard Formation, Texas) and Implications for the Early Uintan in Trans-Pecos Texas. PLoS ONE 9(7): e101516. doi:10.1371/journal.pone.0101516.

Cassata, W.S., Shuster, D.L., Renne, P.R., Weiss, B.P., 2010. Evidence for shock heating and constraints on Martian surface temperatures revealed by ${ }^{40} \mathrm{Ar} /{ }^{39} \mathrm{Ar}$ thermochronometry of Martian meterorites. Geochimica Cosmochimica et Acta 74, 6900-6920.

Chamberlain, K.J., Wilson, C.J.N., Wooden, J.L., Charlier, B.L.A., Ireland, T.R., 2014a. New perspectives on the Bishop Tuff from zircon textures, ages and trace elements. Journal of Petrology 55, 395-426.

Chamberlain, K.J., Morgan, D.J., Wilson, C.J.N., 2014b. Timescales of mixing and mobilisation in the Bishop Tuff 
601

602

603

604

605

606

607

608

609 magma body: perspectives from diffusion chronometry. Contributions to Mineralogy and Petrology 168, doi: 10.1007/s00410-014-1034-2.

Channell, J.E.T., Mazaud, A., Sullivan, P., Turner, S., Raymo M.E., 2002. Geomagnetic excursions and paleointensities in the 0.9-2.15 Ma interval of the Matuyama Chron at ODP Site 983 and 984 (Iceland Basin). Journal of Geophysical Research 107, 10.1029/2001JB000491.

Channell, J.E.T., Xuan, C., Hodell, D.A., 2009. Stacking paleointensity and oxygen isotope data for the last $1.5 \mathrm{Myr}$ (PISO-1500). Earth Planet. Sci. Lett. 283, 14-23.

Christiansen, R.L., 2001. The Quaternary and Pliocene Yellowstone Plateau Volcanic Field of Wyoming, Idaho, and Montana, U.S. Geological Survey Professional Paper 729-G, 1-156.

Coble, M.A., Grove, M., Calvert, A.T., 2011. Calibration of Nu-Instruments Noblesse multicollector mass spectrometers for argon isotopic measurements using a newly developed reference gas. Chemical Geology 290, 7587.

Condon, D.J., Mclean, N., Noble, S.R., and Bowring, S.A., 2010. Isotopic composition $\left({ }^{238} \mathrm{U} /{ }^{235} \mathrm{U}\right)$ of some commonly used uranium reference materials. Geochimica et Cosmochimica Acta 74, 7127-7143, doi: 10.1016/j.gca.2010.09.019.

Condon, D.J., Schoene, B., McLean, N.M., Bowring, S.A., and Parrish, R.R., 2015. Metrology and traceability of U$\mathrm{Pb}$ isotope dilution geochronology (EARTHTIME Tracer Calibration Part I). Geochimica et Cosmochimica Acta, 117, doi: 10.1016/j.gca.2015.05.026.

Crowley, J. L., Schoene, B., Bowring, S.A., 2007. U-Pb dating of zircon in the Bishop Tuff at the millennial scale, Geology 35, 1123-1126, doi:10.1130/G24017A.1.

Deino, A., Potts, R., 1990. Single-crystal ${ }^{40} \mathrm{Ar} /{ }^{39} \mathrm{Ar}$ dating of the Ororgesaile Formation, southern Kenya rift. Journal of Geophysical Research 95, 8453-8470.

DiMaggio, E.N., Campisano, C.J. Rowan, J., Dupont-Nivet, G., Deino, A.L., Bibi, F., Lewis, M.L., Souron, A., Garello, D., Werdelin, L., Reed, K.E., Arrowsmith, J.R., 2015. Late Pliocene fossiliferous sedimentary record and the environmental context of early Homo from Afar, Ethiopia. Science 347, 1355-1359.

Elder, W.P., 1988. Geometry of Upper Cretaceous bentonite beds: Implications about volcanic source areas and paleowind patterns, western interior, United States. Geology 16, 835-838.

Gansecki, C.A., Mahood, G.A., McWilliams, M., 1998. New ages for the climactic eruptions at Yellowstone; singlecrystal ${ }^{40} \mathrm{Ar} /{ }^{39} \mathrm{Ar}$ dating identifies contamination. Geology 26, 343-346.

Gleadow, A., Harrison, M., Kohn, B., Lugo-Zazueta, R., Phillips, D., 2015. The Fish Canyon Tuff: A new look at an old low-temperature thermochronology standard. Earth and Planetary Science Letters 424, 95-108.

Heizler, M.T., EARTHTIME working group, 2008. Argon laboratory intercomparison efforts for the EARTHTIME initiative. Geophysical Research Abstracts 10 EGU2008-A-11478.

Heizler, M.T., 2012. Higher Precision: Opening A new ${ }^{40} \mathrm{Ar} /{ }^{39} \mathrm{Ar}$ can of worms. Abstract V21E-02, 2012 Fall Meeting, AGU, San Francisco, Calif., 3-7 Dec.

Heizler, M.T., Jicha, B.R., Koppers, A.A.P., Miggins, D.P., 2015. ${ }^{40} \mathrm{Ar} /{ }^{39} \mathrm{Ar}$ interlaboratory calibration into the Holocene, AGU fall meeting abstract V53H-07, San Francisco, CA, 14-18 December.

Hiess, J., Condon, D.J., McLean, N., Noble, S.R., 2012. ${ }^{238} \mathrm{U} /{ }^{235}$ U Systematics in Terrestrial Uranium-Bearing Minerals: Science 335, 1610-1614, doi: 10.1126/science.1215507. 

Quaternary volcanic field in eastern California, Geosphere, 10, 1315-1365.

Hoffmann, D.L., Richards, D.A., Elliott, T.R., Smart, P.L., Coath, C.D., Hawkesworth, C.J., 2005. Characterisation of secondary electron multiplier nonlinearity using MCICPMS. International Journal of Mass Spectrometry 244, 97108.

Horng, C.S., Lee, M.Y., Pälike, H., Wei, K.-Y., Liang, W.T., Iizuka, Y., Torii, M., 2002. Astronomically calibrated ages for geomagnetic reversals within the Matuyama Chron. Earth Planets Space 54, 679-690.

Ireland T.R., 2013. Recent developments in isotope-ratio measurements for geochemistry and cosmochemistry. Review of Scientific Instruments 84, 011101.

Jicha, B.R., Rhodes, J.M., Singer, B.S., Garcia, M.O., 2012. ${ }^{40} \mathrm{Ar} /{ }^{39} \mathrm{Ar}$ geochronology of submarine Mauna Loa volcano, Hawaii, Journal of Geophysical Research, 117, B09204, doi:10.1029/2012JB009373.

Kellett, D., Joyce, N., 2014. Analytical details of single- and multicollection ${ }^{40} \mathrm{Ar} /{ }^{39} \mathrm{Ar}$ measurements for conventional step-heating and total-fusion age calculation using the Nu Noblesse at the Geological Survey of Canada. Geological Survey of Canada Technical Note 8, 1-21.

Kennedy, W.J., Walaszczyk, I., Cobban, W.A., 2005.The Global Boundary Stratotype Section and Point for the base of the Turonian Stage of the Cretaceous; Pueblo, Colorado, U.S.A.: Episodes 28, 93-104.

Kuiper, K.F., Hilgen, F.J., Steenbrink, J., Wijbrans, J.R., 2004. ${ }^{40} \mathrm{Ar}{ }^{39} \mathrm{Ar}$ ages of tephras intercalated in astronomically tuned Neogene sedimentary sequences in the eastern Mediterranean. Earth \& Planetary Science Letters 222, 583-597.

Kuiper, K.F., Deino, A., Hilgen, F.J., Krijgsman, W., Renne, P.R., Wijbrans, J.R., 2008. Synchronizing rock clocks of Earth history. Science 320, 500-504.

Lanphere, M.A., Champion, D.E., Christiansen, R.L., Izett, G.A., Obradovich, and J.D., 2002. Revised ages for tuffs of the Yellowstone Plateau volcanic field: Assignment of the Huckleberry Ridge Tuff to a new geomagnetic polarity event. Geological Society of America Bulletin 114, 559-568.

Lee, J.-Y., Marti, K., Severinghaus, J.P., Kawamura, K., Yoo, H.-S., Lee, J.B. \& Kim, J.S., 2006. A redetermination of the isotopic abundance of atmospheric Ar. Geochimica et Cosmochimica Acta 70, 4507-4512.

Lo Bello, G. Féraud, C.M. Hall, D. York, P. Lavina, M. Bernat, 1987. ${ }^{40} \mathrm{Ar} /{ }^{39} \mathrm{Ar}$ step-heating and laser fusion dating of a Quaternary pumice from Neschers, Massif Central, France: the defeat of xenocrystic contamination. Chemical Geology 66, 61-71.

Mark, D.F., Barfod, D., Stuart, F.M. Imlach, J., 2009. The ARGUS multicollector noble gas mass spectrometer: Performance for 40Ar/39Ar geochronology, Geochemistry, Geophysics, Geosystems 10, Q0AA02, doi:10.1029/2009GC002643.

Matthews, N.E., Vazquez, J.A., Calvert, A.T., 2015. Age of the Lava Creek supereruption and magma chamber assembly at Yellowstone based on $40 \mathrm{Ar} / 39 \mathrm{Ar}$ and $\mathrm{U}-\mathrm{Pb}$ dating of sanidine and zircon crystals. Geochemistry, Geophysics, Geosystems 16, doi:10.1002/2015GC005881.

Mattinson, J.M., 2005. Zircon U/Pb chemical abrasion (CATIMS) method: Chemical Geology 220, 47-66, doi: $10.1016 /$ j.chemgeo 2005.03 .011 .

McDougall, I., Brown, F.H., Vasconcelos, P.M., Cohen, B. E., Thiede, D.S., Buchanan, M.J., 2011. New single crystal ${ }^{40} \mathrm{Ar} /{ }^{39} \mathrm{Ar}$ ages improve time scale for deposition of the Omo Group, Omo-Turkana Basin, East Africa. Journal of the Geological Society 169, $213-226$. 
McDougall, I., Harrison T.M., 1999. In Geochronology and Thermochronology by the ${ }^{40}$ Ar ${ }^{39}$ Ar Method, second ed., Oxford University Press, New York. 269 pp.

McLean, N.M., Bowring, J.F., and Bowring, S.A., 2011. An algorithm for U-Pb isotope dilution data reduction and uncertainty propagation. Geochemistry Geophysics Geosystems 12, Q0AA18, doi: 10.1029/2010GC003478.

McLean, N.M., Condon, D.J., Schoene, B., Bowring, S.A., 2015. Evaluating uncertainties in the calibration of isotopic reference materials and multi-element isotopic tracers (EARTHTIME Tracer Calibration Part II): Geochimica et Cosmochimica Acta 164, 481-501.

Mercer, C.M., Young, K.E., Weirich, J.R., Hodges, K.V., Jolliff, B.L., Wartho, J., van Soest, M.C., 2015. Refining lunar impact chronology through high spatial resolution ${ }^{40} \mathrm{Ar} /{ }^{39} \mathrm{Ar}$ dating of impact melts. Science Advances $1: \mathrm{e} 1400050$.

Merrihue, C., Turner, G., 1966. Potassium-argon dating by activation with fast neutrons. Journal of Geophysical Research 71, 2852-2857.

Meyers, S.R., Siewert, S.E., Singer, B.S., Sageman, B.B., Condon, D.J., Obradovich, J.D., Jicha, B.R., Sawyer, D.A., 2012. Intercalibration of radioisotopic and astrochronologic time scales for the Cenomanian-Turonian boundary interval, Western Interior Basin, USA. Geology 40, 7-10.

Min, K., Mundil, R., Renne, P.R., Ludwig, K.R., 2000. A test for systematic errors in ${ }^{40} \mathrm{Ar} /{ }^{39} \mathrm{Ar}$ geochronology through comparison with $\mathrm{U} / \mathrm{Pb}$ analysis of a 1.1-Ga rhyolite. Geochimica et Cosmochimica Acta 64, 73-98.

Morgan, L.E., Mark, D.F., Imlach, J., Barfod, D., Dymock, R., 2013. FCs-EK: A new sampling of the Fish Canyon Tuff ${ }^{40} \mathrm{Ar} /{ }^{39} \mathrm{Ar}$ neutron flux monitor. In: Jourdan, F., Mark, D. F. \& Verati, C. (eds) Advances in ${ }^{40} \mathrm{Ar} /{ }^{39} \mathrm{Ar}$ Dating: from Archaeology to Planetary Sciences. Geological Society of London Special Publications 378, 63-68.

Mundil, R., Ludwig, K.R., Metcalfe, I., Renne, P. R., 2004. Age and timing of the Permian mass extinctions: U/Pb dating of closed-system zircons. Science 305, 1760-1763.

Nelms, S.M., Quétel, C.R., Prohaska, T., Vogel, J., Taylor, P.D.P., 2001. Evaluation of detector dead time calculation models for ICP-MS. Journal of Analytical Atomic Spectrometry 16, 333-338.

Nomade, S., Renne, P.R., Vogel, N., Deino, A.L., Sharp, W.D., Becker, T.A., Jaouni A.R., Mundil R., 2005. Alder Creek sanidine (ACs-2): a Quaternary ${ }^{40} \mathrm{Ar} /{ }^{39} \mathrm{Ar}$ dating standard tied to the Cobb Mountain geomagnetic event. Chemical Geology 218, 315-338.

Nygren, U., Ramebäck, H., Vesterlund, A., Berglund, M., 2011. Consequences of and potential reasons for inadequate dead time measurements in isotope ratio mass spectrometry. International Journal of Mass Spectrometry 300, 21-25.

Obradovich, J., 1993. A Cretaceous time scale, in Caldwell, W.G.E., and Kauffman, E.G., eds., Evolution of the Western Interior Basin: Geological Society of Canada Special Paper 39, 379-396.

Obradovich, J.D., 1992. Geochronology of the late Cenozoic volcanism of Yellowstone National Park and adjoining areas, Wyoming and Idaho, U.S. Geological Survey Open File Report 92-408, 1-47.

Panaiotu, C.G., Jicha, B.R, Singer, B.S., Ţugui, A., Seghedi, I., Panaiotu, A.G., Necula, C., $2013 .{ }^{40} \mathrm{Ar} /{ }^{39} \mathrm{Ar}$ chronology and paleomagnetism of Quaternary basaltic lavas from the Perşani Mountains (East Carpathians), Physics of the Earth and Planetary Interiors 221, 1-14, http://dx.doi.org/10.1016/j.pepi 013.06.007.

Philips D., Matchan, E.L., 2013. Ultra-high precision ${ }^{40} \mathrm{Ar} /{ }^{39} \mathrm{Ar}$ ages for Fish Canyon Tuff and Alder Creek Rhyolite sanidine: new dating standards required? Geochim. Cosmochim. Acta 121, 229-239. 
Powell, R., Hergt, J., Woodhead, J., 2002. Improving isochron calculations with robust statistics and the bootstrap. Chemical Geology 185, 191-204.

Renne, P.R., Sharp, W.D., Deino, A.L., Orsi, G., Civetta, L., 1997. ${ }^{40} \mathrm{Ar} /{ }^{39} \mathrm{Ar}$ dating into the historic realm: calibration against Pliny the Younger. Science 277, 1279-1280.

Renne, P.R., Swisher, C.C., III, Deino, A.L., Karner, D.B., Owens, T., DePaolo, D.J., 1998. Intercalibration of standards, absolute ages and uncertainties in ${ }^{40} \mathrm{Ar} /{ }^{39} \mathrm{Ar}$ dating. Chemical Geology $145,117-152$.

Renne, P.R., Mundil, R., Balco, G., Min, K., Ludwig, K.R., 2010. Joint determination of ${ }^{40} \mathrm{~K}$ decay constants and ${ }^{40} \mathrm{Ar} * /{ }^{40} \mathrm{~K}$ for the Fish Canyon sanidine standard, and improved accuracy for ${ }^{40} \mathrm{Ar} /{ }^{39} \mathrm{Ar}$ geochronology. Geochimica Cosmochimica et Acta 74, 5349-5367.

Renne, P.R., Balco, G., Ludwig, K.R., Mundil, R., Min, K., 2011. Response to the comment by W.H. Schwarz et al. on "Joint determination of ${ }^{40} \mathrm{~K}$ decay constants and ${ }^{40} \mathrm{Ar} *{ }^{40} \mathrm{~K}$ for the Fish Canyon sanidine standard, and improved accuracy for ${ }^{40} \mathrm{Ar} /{ }^{39} \mathrm{Ar}$ geochronology" by P.R. Renne et al. (2010). Geochimica et Cosmochimica Acta 75, 50975100 .

Renne, P.R., Mulcahy, S.R., Cassata, W.S., Morgan, L.E., Kelley, S.P., Hlusko, L.J., Njau, J.K., 2012. Retention of inherited Ar by alkali feldspar xenocrysts in a magma: Kinetic constraints from Ba zoning profiles. Geochimica et Cosmochimica Acta 93, 129-142.

Rivera, T.A., Storey, M., Zeeden, C., Hilgen, F.J., Kuiper, K., 2011. A refined astronomically calibrated ${ }^{40} \mathrm{Ar} /{ }^{39} \mathrm{Ar}$ age for Fish Canyon sanidine. Earth and Planetary Science Letters 311, 420-426.

Rivera, T.A., Storey, M., Schmitz, M.D. Crowley, J.L., 2013. Age intercalibration of ${ }^{40} \mathrm{Ar} /{ }^{39} \mathrm{Ar}$ sanidine and chemically distinct $\mathrm{U} / \mathrm{Pb}$ zircon populations from the Alder Creek Rhyolite Quaternary geochronology standard. Chemical Geology 345, 87-98.

Rivera, T.A., Schmitz, M.D., Crowley, J.L. Storey, M., 2014. Rapid magma evolution constrained by zircon petrochronology and ${ }^{40} \mathrm{Ar} /{ }^{39} \mathrm{Ar}$ sanidine ages for the Huckleberry Ridge Tuff, Yellowstone, USA. Geology 42, 643646.

Rivera, T.A., Jicha, B.R., 2015. ${ }^{40} \mathrm{Ar} /{ }^{39} \mathrm{Ar}$ single crystal sanidine dates for the Lava Creek Tuff (member B). EarthChem Library. http://dx.doi.org/10.1594/IEDA/100549.

Saxton, J.M., 2015. A method for measurement of ${ }^{36} \mathrm{Ar}$ without $\mathrm{H}^{35} \mathrm{Cl}$ interference. Chemical Geology 409, 112117.

Schlanger, S.O., Jenkyns, H.C., 1976. Cretaceous oceanic anoxic events: Causes and consequences: Geologie en Mijnbouw 55, 179-184.

Schmitz, M.D., Bowring, S.A., 2001. U-Pb zircon and titanite systematics of the Fish Canyon Tuff. An assessment of high precision $\mathrm{U}-\mathrm{Pb}$ geochronology and its application to young volcanic rocks. Geochimica Cosmochimica et Acta 65, 2571-2587.

Schmitz, M.D., Schoene, B., 2007. Derivation of isotope ratios, errors, and error correlations for U-Pb geochronology using $\left.{ }^{205} \mathrm{~Pb}-{ }^{235} \mathrm{U}-{ }^{233} \mathrm{U}\right)$-spiked isotope dilution thermal ionization mass spectrometric data. Geochemistry Geophysics Geosystems 8, 1-20, doi: 10.1029/2006GC001492.

Schmitz, M.D., Kuiper, K.F., 2013. High-precision geochronology. Elements 9, 25-30.

Schoene, B., Crowley, J.L., Condon, D.C., Schmitz, M.D., Bowring, S.A., 2006. Reassessing the uranium decay constants for geochronology using ID-TIMS U-Pb data. Geochimica et Cosmochimica Acta 70, 426-445. 
Sharp, W. D., Renne, P.R., 2005. The ${ }^{40} \mathrm{Ar} /{ }^{39} \mathrm{Ar}$ dating of core recovered by the Hawaii Scientific Drilling Project (phase 2), Hilo, Hawaii, Geochemistry, Geophysics, Geosystems, 6, Q04G17, doi:10.1029/2004GC000846.

Simon, J.I., Weis, D., DePaolo, D.J., Renne, P.R., Mundil, R., Schmitt, A.K., 2014. Assimilation of preexisting Pleistocene intrusions at Long Valley by periodic magma recharge accelerates rhyolite generation: rethinking the remelting model. Contributions to Mineralogy and Petrology 167, 955.

Singer, B.S., 2014. A Quaternary geomagnetic instability time scale: Quaternary Geochronology 21, 29-52, doi:10.1016/j.quageo.2013.10.003.

Spell, T.L., McDougall, I., 2003. Characterization and calibration of ${ }^{40} \mathrm{Ar} /{ }^{39} \mathrm{Ar}$ dating standards. Chemical Geology 198, 189-211.

Turrin, B.D., Donnelly-Nolan, J.M., Hearn Jr., B.C., 1994. ${ }^{40} \mathrm{Ar} /{ }^{39} \mathrm{Ar}$ ages from the rhyolite of Alder Creek, California: age of the Cobb Mountain normal-polarity subchron revisited. Geology 22, 251-254.

Wotzlaw, J.F., Bindeman, I.N., Stern, R.A., D‘Abzac, F.X., Schaltegger, U., 2015. Rapid heterogeneous assembly of multiple magma reservoirs prior to Yellowstone supereruptions. Scientific reports 5, 14026, doi: 10.1038/srep14026.

Wotzlaw, J.F., Schaltegger, U., Frick, D.A., Dungan, M.A., Gerdes, A., Gunther, D., 2013. Tracking the evolution of large-volume silicic magma reservoirs from assembly to supereruption, Geology, 41, 867-870.

Zeeden, C., Rivera, T.A., Storey, M., 2014. An astronomical age for the Bishop Tuff and concordance with radioisotopic dates, Geophysical Research Letters 41, 3478-3484, doi:10.1002/2014GL059899.

\section{Figures and captions}

Fig. 1. (A) Typical analytical blank, which includes exposure to getters for 120 seconds and cryo trap for an additional 60 seconds. Scan over $\mathrm{m} / \mathrm{e} 36$ in IC3 collector showing that ${ }^{36} \mathrm{Ar}+\mathrm{H}^{35} \mathrm{Cl}$ can be partially resolved from a ${ }^{36} \mathrm{Ar}+\mathrm{H}^{35} \mathrm{Cl}+{ }^{12} \mathrm{C}_{3}$ sum peak at m/e 36. Y-axis spans 0 to 50 counts per second (cps). (B) A new standard gas developed in February 2015. Scale (in counts per second, cps) for IC0 is 0-400,000, IC1 is $0-0,000$, and IC3 is $0-3,000 .{ }^{37} \mathrm{Ar}$ is not present in the standard gas. Solid vertical black line indicates where measurements are made for step 1 of analytical routine.

Fig. 2. ${ }^{40} \mathrm{Ar} /{ }^{36} \mathrm{Ar}$ vs ${ }^{40} \mathrm{Ar}$ signal size (cps) for detectors (A) ICO and (B) IC1. Both ICO and IC1 detectors exhibit linearity over the range in count rates that are typical of the signals for the samples analyzed in this study. For IC0, the slope of the line is $6 e-7 x+298.55$ for signals from $50,000 \mathrm{cps}$ to $400,000 \mathrm{cps}$ and $-7 \mathrm{e}-7 \mathrm{x}+298.77$ for signals from $50,000 \mathrm{cps}$ to $600,000 \mathrm{cps}$. A change in slope appears to occur with signals greater than $\sim 630,000 \mathrm{cps}$ as the slope of the line fit through 50,000 to 750,000 cps has a slope of $-2 \mathrm{e}-6 \mathrm{x}+298.95$. This suggests that:1) collector nonlinearity begins to occur with signals $>630,000 \mathrm{cps}$ and 2) the instrument dead time correction is no longer appropriate for these large signals.

Fig. 3. Standard gas composition as determined by single collector measurements in both IC0 and IC1 collectors. Each standard gas measurement ( $\pm 2 \sigma$ uncertainty) shown in these panels has been blank and mass bias-corrected. (A) ${ }^{40} \mathrm{Ar} /{ }^{39} \mathrm{Ar}(\mathrm{B}){ }^{39} \mathrm{Ar} /{ }^{36} \mathrm{Ar}$. (C) ${ }^{36} \mathrm{Ar} /{ }^{38} \mathrm{Ar}$. Solid lines represent weighted mean values. Dashed lines are the uncertainties in the weighted mean at the $95 \%$ confidence level. We focused on evaluating select isotope ratios $\left({ }^{36} \mathrm{Ar} /{ }^{38} \mathrm{Ar}\right.$ in Oct 2012 and ${ }^{40} \mathrm{Ar} /{ }^{39} \mathrm{Ar}$ in Oct 2013) at certain points throughout this 18 month period.

Fig. 4. Comparison of ${ }^{40} \mathrm{Ar} /{ }^{39} \mathrm{Ar}$ ages determined for Alder Creek rhyolite sanidine sample ACs- 2 since 2005. ${ }^{40} \mathrm{Ar} /{ }^{39} \mathrm{Ar}$ ages are shown with $\pm 2 \sigma$ analytical uncertainties only. Some of the published ages have been recalculated so that all the data in this figure are relative to $28.201 \mathrm{Ma}$ for the Fish Canyon sanidine. 
The commonly used age from Nomade et al. (2005) is shown as a dotted line. Gray band indicates range

831

832

833

834

835

836

837

838

839

840

841

842

843

844

845

846

847

848

849

850

851

852

853

854

855

856

857

858

859

860

861

862

863

864

865

866

867

868

869

870

871

872

873

874

875

876

877

878

879

880 in ages generated during the EARTHTIME laboratory intercalibration experiment (Heizler et al., 2008). Recent experiments including all the data collected using multi-collector mass spectrometers (Phillips and Matchan, 2013; Rivera et al., 2013) give ages that are significantly younger than the Nomade et al. (2005) age. Our preferred age (red dotted line) for AC-2 based on a weighted mean of the Rivera et al. (2013) dates and our plateau ages and total fusion dates is $1.1864 \pm 0.0003 / 0.0012 \mathrm{Ma}$ ( $95 \%$ confidence analytical/full external).

Fig. 5. Comparison of ACS-2 total fusion analysis performed on single collector MAP 215-50 (left column; Singer, 2014), Noblesse (middle column), Argus VI (right column; Phillips and Matchan, 2013). MAP215-50 data collected on a multiplier operated in analogue mode. Integration time for Argus VI data is $33.55 \mathrm{sec}$. Data from instruments is shown before any background or blank correction. Note that whereas there is some reduction in the uncertainty of the ${ }^{36} \mathrm{Ar}$ intercept using the Noblesse, there is marked reduction in the uncertainty associated with the ${ }^{40} \mathrm{Ar}$ and ${ }^{39} \mathrm{Ar}$ intercepts.

Fig. 6. Comparison of ${ }^{40} \mathrm{Ar} /{ }^{39} \mathrm{Ar}$ ages determined for Fish Canyon sanidine sample FC-2. All ${ }^{40} \mathrm{Ar} /{ }^{39} \mathrm{Ar}$ ages are shown with analytical uncertainties only and are relative to 28.201 Ma for the Fish Canyon sanidine (Kuiper et al., 2008). Note that all total fusion data were performed on single crystals except for that of Phillips and Matchan, (2013), which fused 2-4 crystals per analysis. Our single crystal total fusion experiments gave a range in dates spanning $\sim 88 \mathrm{ka}$ and thus have a MSWD of 3.6. Overall the range in dates is similar to those of the previous studies. Only 6 of the 16 single crystal incremental heating experiments gave statistically acceptable plateaus (filled red boxes). The total fusion ages for the crystals which did not yield plateaus are shown as open boxes. CA-IDTIMS U-Pb zircon dates are from Wotzlaw et al. (2013); the youngest zircon (solid black bar) is $28.196 \pm 0.038 \mathrm{Ma}$. We recognize that there are other published U-Pb zircon datasets for the Fish Canyon Tuff. However, the purpose of the figure is to highlight the age complexity within the FCT not select an absolute age for the FCT.

Fig. 7. Age spectrum diagrams for Fish Canyon sanidine (FC-2). Ages are calculated relative to and age of 28.201 Ma for FCs. Several of the discordant age spectra show a gas release pattern that is similar to those observed by Phillips and Matchan (2013) (left). Only 6 of the 16 single crystal incremental heating experiments gave statistically acceptable plateaus, two of which are shown (right).

Fig. 8. Comparison of ${ }^{40} \mathrm{Ar} /{ }^{39} \mathrm{Ar}$ sanidine total fusion dates from Lava Creek Tuff member B from Matthews et al. (2015) and this study to the CA-ID-TIMS U-Pb dates of Wotzlaw et al. (2015). The small analytical uncertainties generated using the Noblesse allow us to distinguish between antecrysts that are a little as $8 \mathrm{kyr}$ older than the juvenile population of dates that give a weighted mean age of $630.9 \pm$ $1.2 / 2.7 \mathrm{ka}$. Uncertainties are given at $95 \%$ confidence level, and reported in the form $\pm \mathrm{X} / \mathrm{Y}$ where $\mathrm{X}$ is the analytical uncertainty and $\mathrm{Y}$ includes systematic or full external uncertainties. External error propagation methods follow the algorithms of Kuiper et al. (2008). Horizontal boxes represent range of analytical uncertainty for each dataset. SCF = single crystal fusion. For complete data, see Rivera and Jicha, 2015 or electronic supplement.

Fig. 9. Compilation of all ${ }^{40} \mathrm{Ar} /{ }^{39} \mathrm{Ar}$ and U-Pb data for the B bentonite of Elder (1988). The B bentonite was sampled at the GSSP Pueblo, Colorado (K07-01B) and in Thayer County, Nebraska (sample 90-O-19 of Obradovich (1993); and NE-08-01 of Meyers et al. (2012) come from the exact same outcrop). The Bighorn River bentonite in Alberta, Canada is interpreted to be the equivalent of the B bentonite (Barker et al. (2011) and references therein. ${ }^{40} \mathrm{Ar} /{ }^{39} \mathrm{Ar}$ multi-crystal sanidine total fusion dates from Meyers et al. (2012) were obtained on a MAP 215-50 single collector instrument versus single crystal total fusions using the Noblesse multi-collector mass spectrometer in this study. Crystals from the same sanidine separate were analyzed in both studies. Youngest U-Pb zircon date from K07-01B is in agreement with the ${ }^{40} \mathrm{Ar} /{ }^{39} \mathrm{Ar}$ ages. Asterisk indicates the U-Pb dates used in Meyers et al. (2012) for this sample, which 
881 gave an age of $94.44 \pm 0.15 \mathrm{Ma}$. Youngest three $\mathrm{U}-\mathrm{Pb}$ dates from Barker et al. (2011) give an age of

$88294.14 \pm 0.12 \mathrm{Ma}$ (MSWD = 0.55), which is within uncertainty of both ${ }^{40} \mathrm{Ar} /{ }^{39} \mathrm{Ar}$ and $\mathrm{U}-\mathrm{Pb}$ ages for the $\mathrm{B}$

883 bentonite in this study and in Meyers et al. (2012). The U-Pb age of $94.29 \pm 0.13 \mathrm{Ma}(\mathrm{MSWD}=2.4)$ as

884 reported by Barker et al. (2011) based on all six zircon dates is older than the all ${ }^{40} \mathrm{Ar} /{ }^{39} \mathrm{Ar}$ and U-Pb ages

885 for the B bentonite. Uncertainties are reported in same manner as Figure 8. 
Figure 1

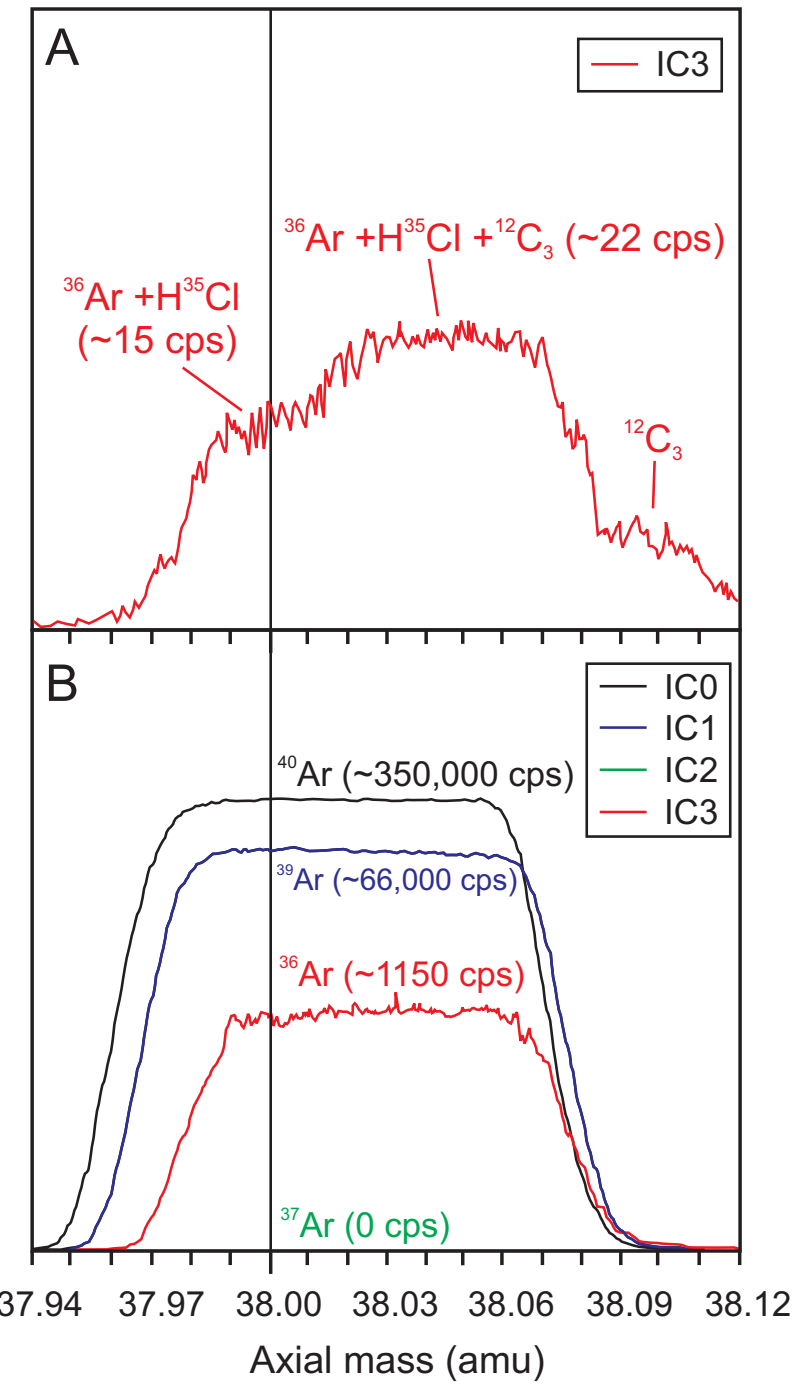


Figure 3

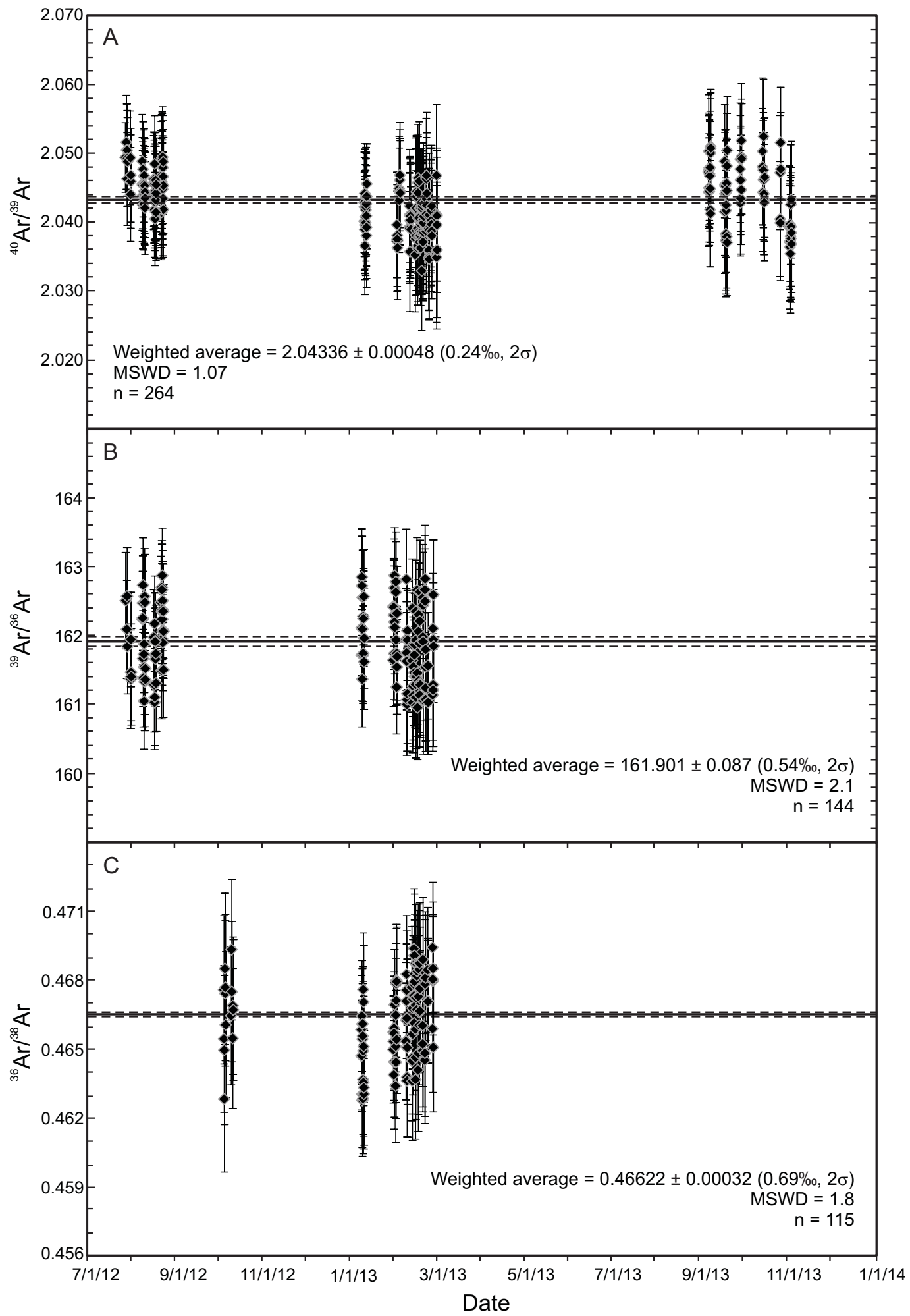




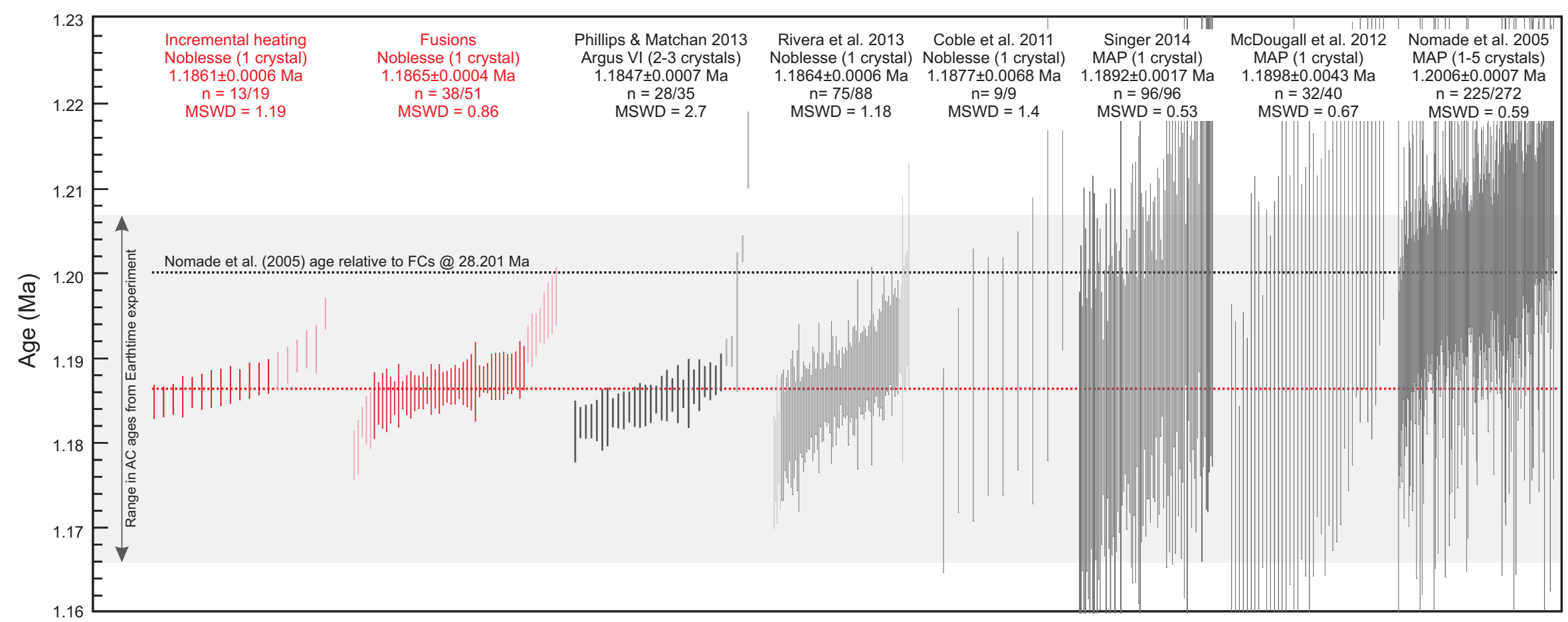



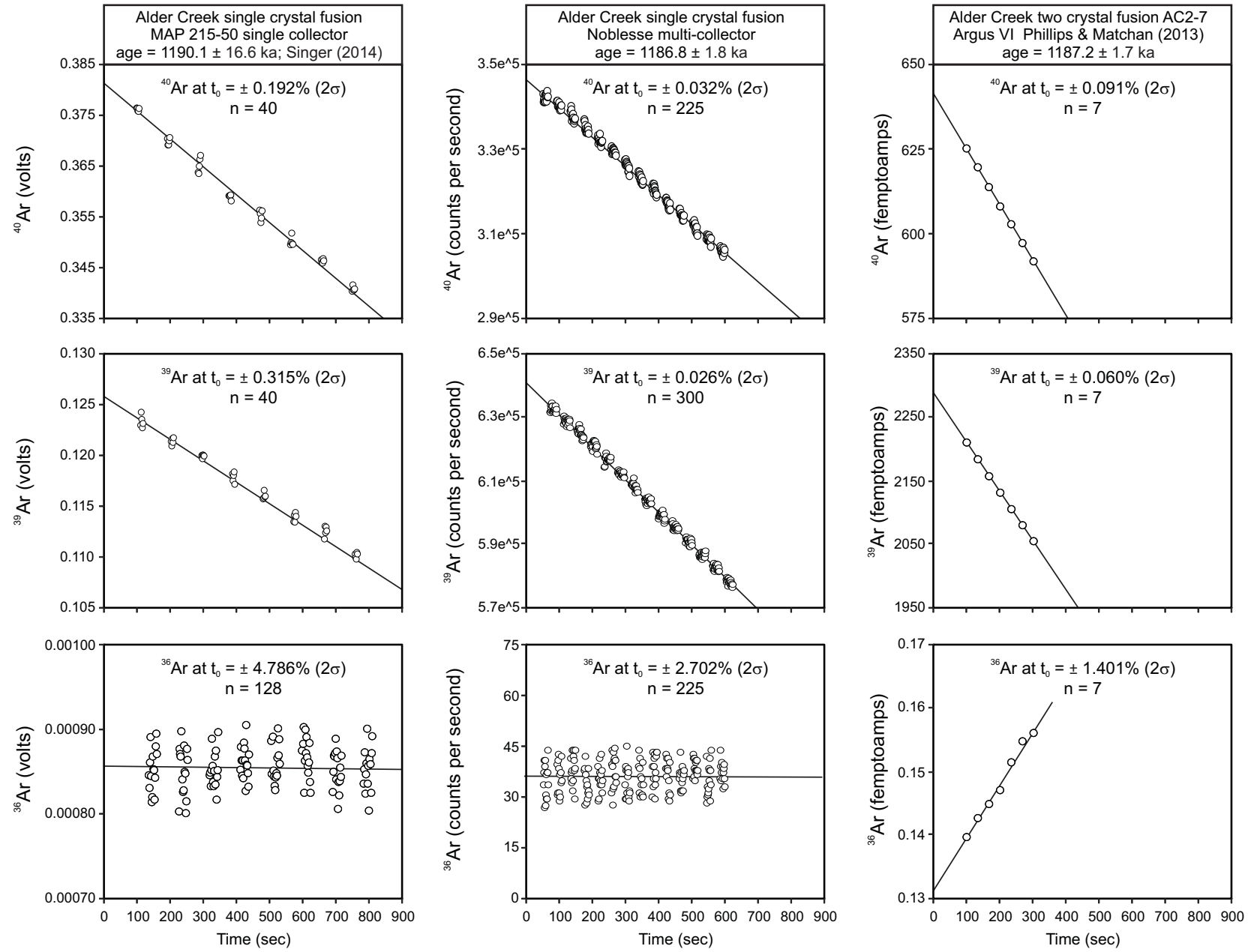


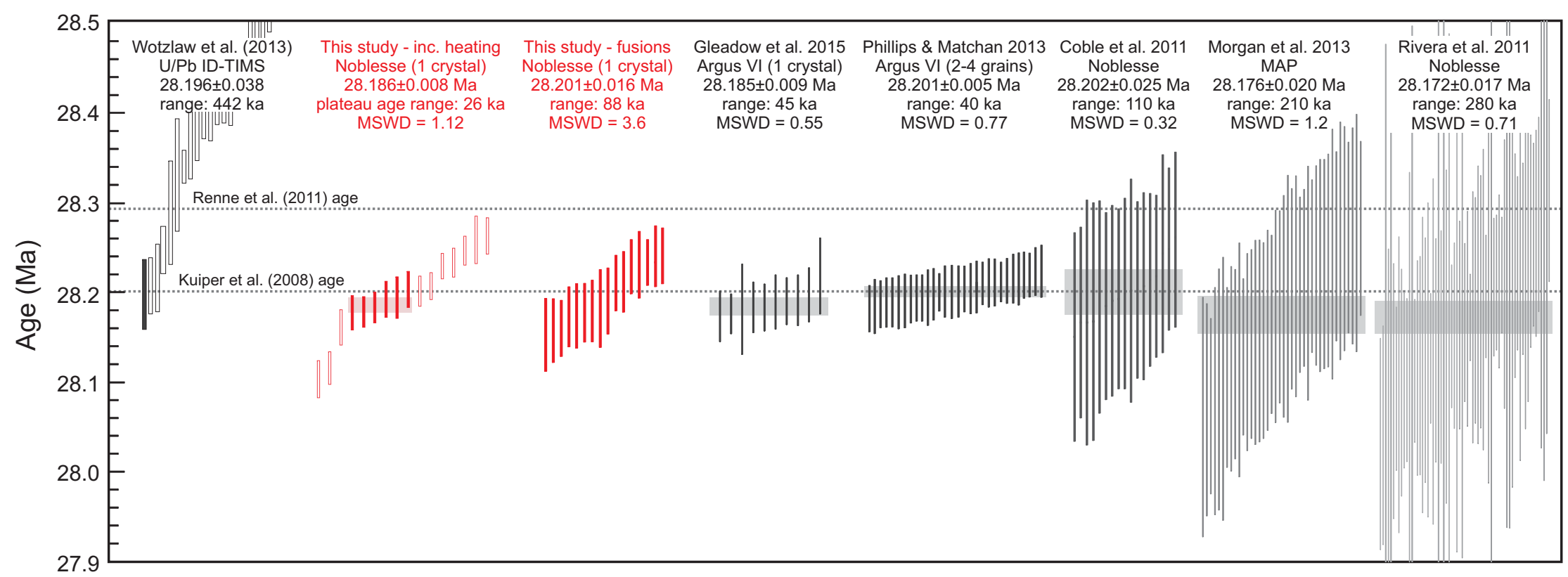


Figure 7
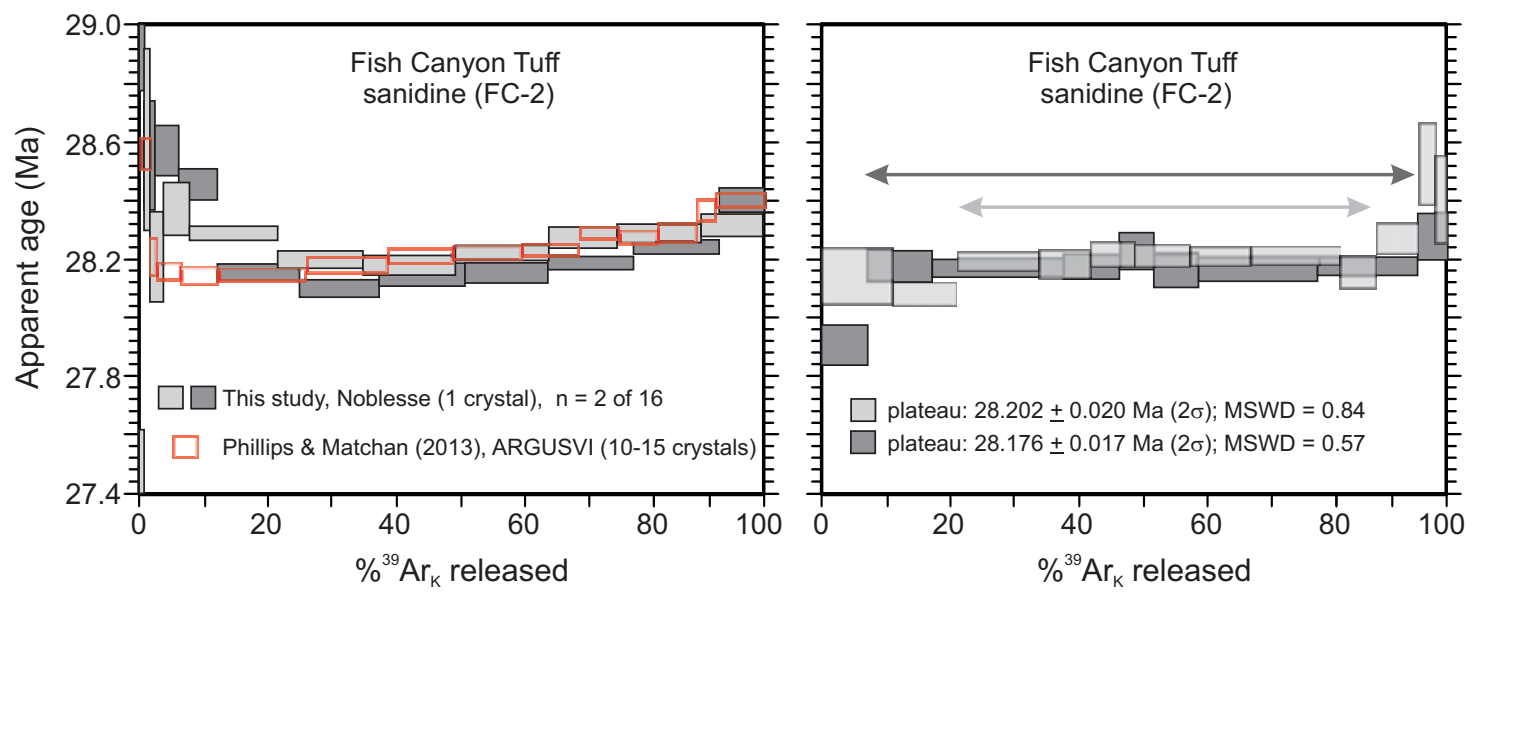

.

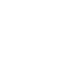

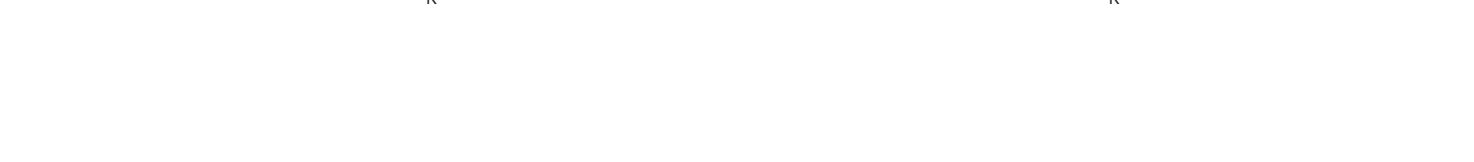

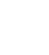

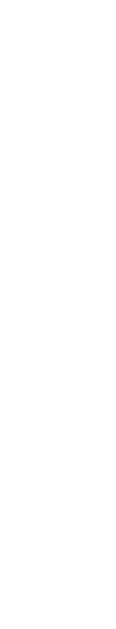


Figure 8
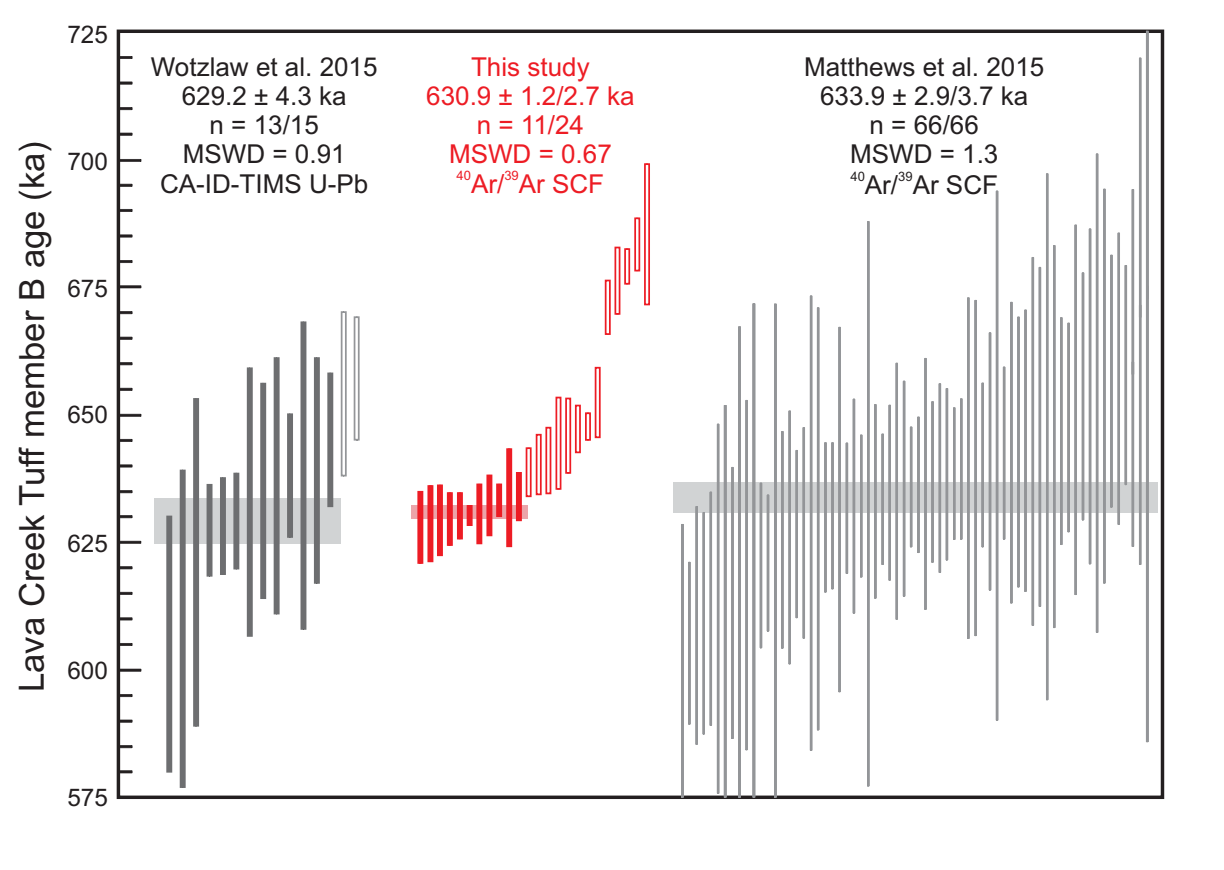


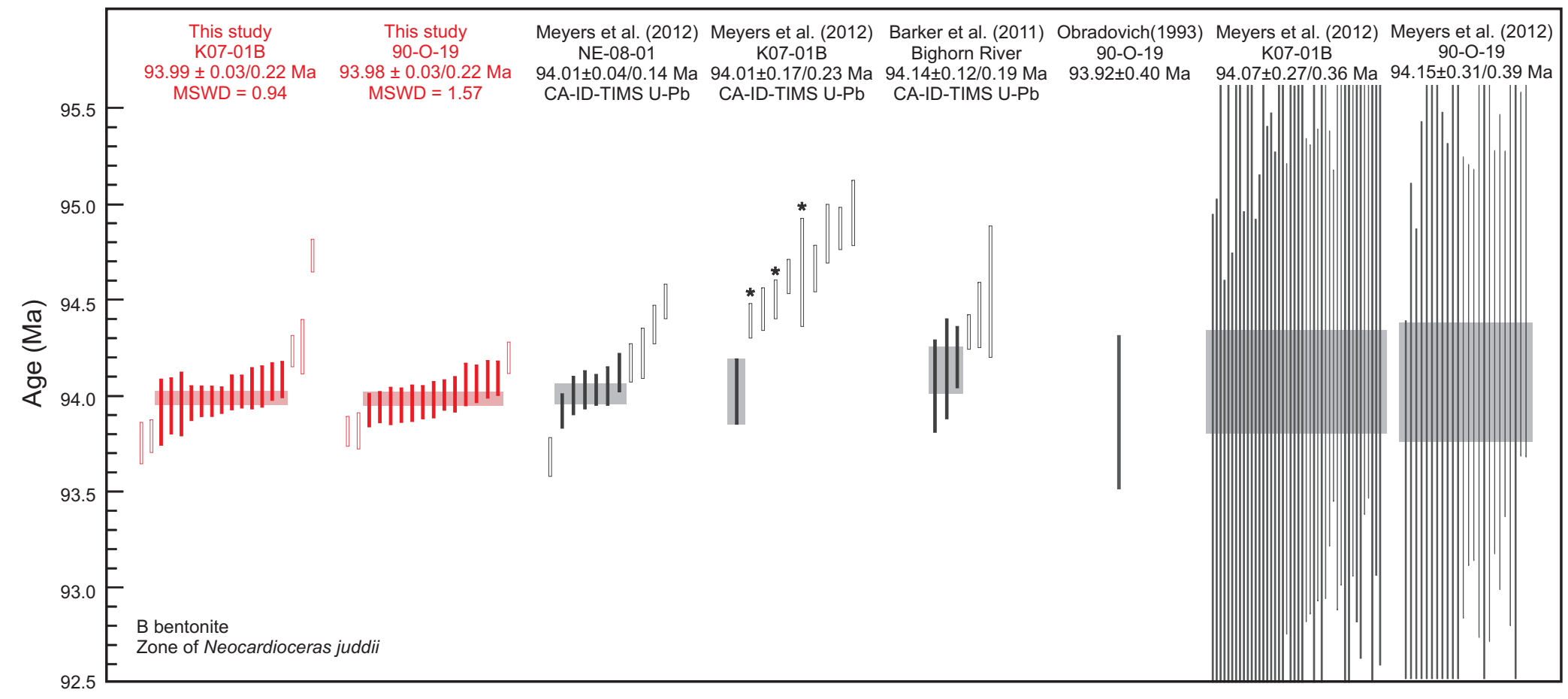


Table 1

Analysis routine and collector configuration for Noblesse with one Faraday, two high mass, and two low mass ion counting electron multipliers (IC). A typical analytical routine requires one peak hop.

\begin{tabular}{lcccccc}
\hline Detector & ICO & IC1 & Faraday & IC2 & IC3 & Integration time \\
\hline Step 1 & ${ }^{40} \mathrm{Ar}$ & ${ }^{39} \mathrm{Ar}$ & - & ${ }^{37} \mathrm{Ar}$ & ${ }^{36} \mathrm{Ar}$ & $15 \mathrm{sec}$ \\
Step 2 & ${ }^{39} \mathrm{Ar}$ & ${ }^{38} \mathrm{Ar}$ & - & ${ }^{36} \mathrm{Ar}$ & & $20 \mathrm{sec}$ \\
\hline
\end{tabular}

